\title{
Calculation and application of clinopyroxene-garnet-plagioclase-quartz geobarometers *
}

\author{
D.P. Moecher, E.J. Essene, and L.M. Anovitz ** \\ Department of Geological Sciences, University of Michigan, Ann Arbor, MI 48109-1063, USA
}

\begin{abstract}
Recently published thermodynamic and experimental data in a variety of chemical systems have been evaluated to derive Gibbs free energies for hedenbergite and pyrope. These were used to calculate the geobarometric equilibria
\end{abstract}

Hedenbergite + Anorthite $=$ Grossular + Almandine

+Quartz: "HD barometer",

Diopside + Anorthite $=$ Grossular + Pyrope + Quartz:

"DI barometer".

We have compared the pressures obtained from these equilibria for garnet-clinopyroxene-orthopyroxene-plagioclasequartz assemblages with the geobarometer

Ferrosilite + Anorthite $=$ Almandine + Grossular + Quartz: "FS barometer".

Pressures calculated for 68 samples containing the above assemblage from a variety of high grade metamorphic terranes indicate that, in general, the HD and DI barometers yield values that are in good agreement with the FS barometer, and that the three barometers are gencrally consistent with constraints from aluminosilicate occurrences. However, in some samples the HD barometer yields pressures up to $2 \mathrm{kbar}$ greater than constraints imposed by the presence of an aluminosilicate phase. Relative to the FS barometer, the HD barometer overestimates pressure by an average of $0.2 \pm 1.0(1 \sigma) \mathrm{kbar}$ and the DI barometer underestimates pressure by an average of $0.6 \pm 1.6(1 \sigma) \mathrm{kbar}$. The pressure discrepancies for the HD and DI barometers are likely to be a result of imprecision in thermodynamic data and activity models for silicates, and not a result of resetting of the clinopyroxene equilibria. The relative imprecision of the DI barometer relative to the FS barometer results from overestimates of pressure by the DI and FS barometers in Fe-rich and Mg-rich systems, respectively. Application of the HD and DI barometers to high grade $\mathrm{Cpx}-\mathrm{Gt}-\mathrm{Pg}-\mathrm{Qz}$ assemblages yields pressures that are generally consistent with other petrologic constraints and geobarometers. It is concluded that the HD and DI barometers can place reasonable constraints on pressure ( $\pm 1 \mathrm{kbar}$ relative to the FS barome-

\footnotetext{
* Contribution No. 447 from the Mineralogical Laboratory of the University of Michigan

** Present address: Department of Geosciences, University of Arizona, Tucson, AZ 85721 USA
}

offprint requests to: D.P. Moecher ter) if not extrapolated to mineral assemblages whose compositions are extremely far removed from the end member system for which the barometers were calibrated.

\section{Introduction}

Major advances in the accuracy and precision of geobarometers have been made in the last decade, in part a result of careful experimental reversal of pressure dependent equilibria (Bohlen et al. 1980; Bohlen and Boettcher 1982; Bohlen et al. 1983a, 1983b; Gasparik 1984a, 1984b; Gasparik and Newton 1984; Bohlen and Liotta 1986; Koziol and Newton 1988), more precise thermodynamic data (e.g. Haselton and Newton 1980; Metz et al. 1983; Bohlen et al. 1983; Robie and Hemingway 1984; Haselton et al. 1987; Robie et al. 1987), and more accurate modeling of activitycomposition relations for mineral phases involved in geobarometric equilibria (e.g., Newton et al. 1980; Newton and Haselton 1981; Ganguly and Saxena 1984; Davidson and Lindsley 1985; Anovitz and Essene 1987a). Reasonably accurate and precise geobarometers now exist for most granulite facies metabasites, charnockites and high grade metapelites, and for some upper amphibolite facies metabasites and metapelites. The above experiments also serve as important constraints on thermodynamic data for mineral phases involved in the particular reaction. In concert with precise thermodynamic data for other phases, the experimentally constrained thermodynamic data may be used to calculate geobarometers that are not easily reversed experimentally. Using this approach we have calculated the location of the pressure dependent reactions

Hedenbergite + Anorthite $=$ Grossular + Almandine + Quartz

$3 \mathrm{CaFeSi}_{2} \mathrm{O}_{6}+3 \mathrm{CaAl}_{2} \mathrm{Si}_{2} \mathrm{O}_{8}=2 \mathrm{Ca}_{3} \mathrm{Al}_{2} \mathrm{Si}_{3} \mathrm{O}_{12}$

$+\mathrm{Fe}_{3} \mathrm{Al}_{2} \mathrm{Si}_{3} \mathrm{O}_{12}+3 \mathrm{SiO}_{2}$

(the "Hedenbergite (HD) barometer") and,

Diopside + Anorthite $=$ Grossular + Pyrope + Quartz

$3 \mathrm{CaMgSi}_{2} \mathrm{O}_{6}+3 \mathrm{CaAl}_{2} \mathrm{Si}_{2} \mathrm{O}_{8}=2 \mathrm{Ca}_{3} \mathrm{Al}_{2} \mathrm{Si}_{3} \mathrm{O}_{12}$

$+\mathrm{Mg}_{3} \mathrm{Al}_{2} \mathrm{Si}_{3} \mathrm{O}_{12}+3 \mathrm{SiO}_{2}$

(the "Diopside (DI) barometer"), in order to expand the range of assemblages for which there exist reasonably pre- 
cise geobarometers. Because garnet, plagioclase and quartz are phases common to both barometers we have chosen to distinguish them on the basis of the particular pyroxene present. Reaction 2 was previously calculated by Newton and Perkins (1982) based on the best available thermochemical data. Their version of Reaction 2 typically underestimated pressure by an average of $2.2 \mathrm{kbar}$ relative to their orthopyroxene geobarometer (Newton and Perkins 1982), which was ascribed to imprecise thermodynamic data.

This paper presents calculations of new calibrations for clinopyroxene-garnet-plagioclase-quartz geobarometers in the system $\mathrm{CaO}-\mathrm{Al}_{2} \mathrm{O}_{3}-\mathrm{FeO}-\mathrm{MgO}-\mathrm{SiO}_{2}$, based on thermodynamic data derived from a number of sources and constrained by a variety of experimental equilibria. The precision and accuracy of these calibrations are tested by comparing pressures obtained for Reactions 1 and 2 against the equilibrium

Ferrosilite + Anorthite $=$ Almandine + Grossular + Quartz

$$
\begin{aligned}
& 6 \mathrm{FeSiO}_{3}+3 \mathrm{CaAl}_{2} \mathrm{Si}_{2} \mathrm{O}_{8}=2 \mathrm{Fe}_{3} \mathrm{Al}_{2} \mathrm{Si}_{3} \mathrm{O}_{12} \\
& +\mathrm{Ca}_{3} \mathrm{Al}_{2} \mathrm{Si}_{3} \mathrm{O}_{12}+3 \mathrm{SiO}_{2}
\end{aligned}
$$

(the "Ferrosilite (FS) barometer"), and the location of the polymorphic transition

Sillimanite $=$ Kyanite

(Richardson et al. 1968; Holdaway 1971; Robie and Hemingway 1984). Reaction 3 is derived by addition of the experimentally reversed reactions

Fayalite + Quartz $=2$ Ferrosilite

$\mathrm{Fe}_{2} \mathrm{SiO}_{4}+\mathrm{SiO}_{2}=\mathrm{FeSiO}_{3}$

(Bohlen et al. 1980) and

$$
\begin{aligned}
& \text { Fayalite }+ \text { Anorthite }=\text { Almandine }+ \text { Grossular } \\
& 3 \mathrm{Fe}_{2} \mathrm{SiO}_{4}+3 \mathrm{CaAl}_{2} \mathrm{Si}_{2} \mathrm{O}_{8} \\
& =\left(2 \mathrm{Fe}_{3} \mathrm{Al}_{2} \mathrm{Si}_{3} \mathrm{O}_{12}+\mathrm{Ca}_{3} \mathrm{Al}_{2} \mathrm{Si}_{3} \mathrm{O}_{12}\right)_{\mathrm{ss}}
\end{aligned}
$$

(where SS is a $2 / 3$ almandine $+1 / 3$ grossular solid solution produced in the experiments, Bohlen et al. 1983a), and has proven to be an extremely useful geobarometer for granulites. Calculations of Reaction 3 as a geobarometer have been presented by Bohlen et al. (1983a), Perkins and Chipera (1985), and Anovitz and Essene (1987a) that differ in the choice of thermodynamic data and garnet mixing model used to calculate the position of the end member reaction (Reaction 3). For these purposes we have used the garnet mixing model of Ganguly and Saxena (1984) with $\mathrm{Ca}-\mathrm{Fe}$ mixing parameters derived by Anovitz and Essene (1987a). Sources of thermodynamic data are discussed in detail in the following sections.

\section{Thermodynamic data}

A variety of sources and experimental studies were used in the compilation of thermodynamic data for the present study. Carefully reversed experiments on Reactions 5, 6 and the reactions

Almandine + Rutile $=$ Ilmenite + Sillimanite + Quartz

$\mathrm{Fe}_{3} \mathrm{Al}_{2} \mathrm{Si}_{3} \mathrm{O}_{12}+3 \mathrm{TiO}_{2}=3 \mathrm{FeTiO}_{3}+\mathrm{Al}_{2} \mathrm{SiO}_{5}+2 \mathrm{SiO}_{2}$
Almandine + Grossular + Rutile $=$ Ilmenite + Anorthite + Quartz

$2 \mathrm{Fe}_{3} \mathrm{Al}_{2} \mathrm{Si}_{3} \mathrm{O}_{12}+\mathrm{Ca}_{3} \mathrm{Al}_{2} \mathrm{Si}_{3} \mathrm{O}_{12}+6 \mathrm{TiO}_{2}$

$=6 \mathrm{FeTiO}_{3}+3 \mathrm{CaAl}_{2} \mathrm{Si}_{2} \mathrm{O}_{8}+3 \mathrm{SiO}_{2}$

(Bohlen et al. 1983b, 1983c; Bohlen and Liotta 1986)

Anorthite $=$ Grossular + Kyanite + Quartz

$3 \mathrm{CaAl}_{2} \mathrm{Si}_{2} \mathrm{O}_{8}=\mathrm{Ca}_{3} \mathrm{Al}_{2} \mathrm{Si}_{2} \mathrm{O}_{12}+2 \mathrm{Al}_{2} \mathrm{SiO}_{5}+\mathrm{SiO}_{2}$

(Koziol and Newton 1988) and

Wollastonite + Anorthite $=$ Grossular + Quartz

$2 \mathrm{CaSiO}_{3}+\mathrm{CaAl}_{2} \mathrm{Si}_{2} \mathrm{O}_{8}=\mathrm{Ca}_{3} \mathrm{Al}_{2} \mathrm{Si}_{3} \mathrm{O}_{12}+\mathrm{SiO}_{2}$

(Newton 1966; Hays 1967; Boettcher 1970; Huckenholz et al. 1975) combined with heat capacity functions and volume data serve to constrain the 1 bar Gibbs free energy $\left(\Delta G_{298}^{\circ}\right)$ of fayalite, ferrosilite, kyanite, grossular, almandine and anorthite. The latter data were compiled by Anovitz and Essene (1987a; Table 1) from a number of sources and comprise part of an internally consistent thermodynamic data set for selected phases in the system $\mathrm{CaO}-\mathrm{FeO}$ $-\mathrm{Al}_{2} \mathrm{O}_{3}-\mathrm{SiO}_{2}\left(-\mathrm{TiO}_{2}\right)$ (Table 1 and 2). Thermodynamic data for diopside (Tables 1 and 2) have been compiled and evaluated by Sharp et al. (1986) from various sources and experiments in the system $\mathrm{CaO}-\mathrm{MgO}-\mathrm{SiO}_{2}-\mathrm{CO}_{2}$. The reader is referred to these sources for a detailed discussion of the methods used in deriving the respective data. Thermodynamic data for enstatite are taken from Robinson et al. (1982), and derivation of thermodynamic data for pyrope and hedenbergite is described below.

There has been considerable discussion concerning the presence of $\mathrm{Al}-\mathrm{Si}$ disorder in synthetic anorthite produced in phase equilibrium experiments such as Reaction 9, and the necessity of adding a configurational entropy term to $S_{298}^{\circ}$ of anorthite in order to fit the experimental reversals (e.g., Gasparik 1984a; Wood and Holloway 1984; Koziol and Newton 1988). Anovitz and Essene (1987a) also address this problem, concluding that use of different values for $S_{298}^{\circ}$ of grossular, and lack of application of thermal expansion and compressibility in phase equilibrium calculations may require an $S_{0}^{\circ}$ term of anorthite in order to fit the reversals. However, the thermodynamic data set derived by Anovitz and Essene (1987a: Tables 1 and 2 of this study) uses an alternative $S_{298}^{\circ}$ for grossular and includes the effects of expansivity and compressibility of solids, providing an adequate fit to the reversals for Reaction 9 and other equilibria. Following their conclusion we do not believe a configurational entropy term is warranted for anorthite.

The loci of relevant equilibria were calculated with a computer program (EQUILI, Wall and Essene unpubl) that solves the relation

$\Delta G_{T_{2}}^{P_{2}}-\Delta G_{T_{1}^{1}}^{P_{1}}=\int_{P_{1}}^{P_{2}} \Delta V d P-\int_{T_{1}}^{T_{2}} \Delta S d T$

with an experimental reversal or a known Gibbs free energy of reaction as the starting point for the calculation. Using EQUILI, reactions are then calculated at 1 bar, $298 \mathrm{~K}$ in order to obtain the Gibbs free energy $\left(A G_{298}^{\circ}\right)$ of each reaction. Algebraic combination of the reactions allows calculation of the $\Delta G_{298}^{\circ}$ of each phase assuming that the $\Delta G_{298}^{\circ}$ of quartz and other simple phases (c.g., hematite, magnetite, wollastonite) are known (Robie et al. 1979; Robinson et al. 1982). Equilibria for which there are no experimental reversals can then be calculated at high $P$ and $T$ using the 1 bar, $298 \mathrm{~K}$ data as a starting point.

Thermodynamic data for hedenbergite (Tables 1,2) are constrained by the following experiments in the system $\mathrm{Ca}-\mathrm{Fe}$ $-\mathrm{Si}-\mathrm{O}$ :

Andradite $=$ Wollastonite + Hematite

$\mathrm{Ca}_{3} \mathrm{Fe}_{2} \mathrm{Si}_{3} \mathrm{O}_{12}=3 \mathrm{CaSiO}_{3}+\mathrm{Fe}_{2} \mathrm{O}_{3}$

(Huckenholz et al. 1974, Suwa et al. 1976), 
Table 1. Molar volume, entropy, entropy coefficients, and Gibbs free energies (relative to elements) of phases involved in thermodynamic calculations

\begin{tabular}{|c|c|c|c|c|c|c|c|c|c|c|}
\hline Phase & $\begin{array}{l}V_{298}^{\circ} \\
\mathrm{cc} / \mathrm{mol}\end{array}$ & Ref & $\begin{array}{l}S_{298}^{\circ} \\
\mathrm{J} / \mathrm{mol} \mathrm{K}\end{array}$ & $\mathrm{A}$ & B & $\mathrm{C}$ & $\mathrm{D}$ & Ref & $\begin{array}{l}\Delta G_{298}^{\circ} \\
\mathrm{kJ} / \mathrm{mol}\end{array}$ & Ref \\
\hline $\mathrm{Ni}$ & 6.59 & 1 & 29.87 & 29.397 & 4.410 & 1.473 & -187.3 & 1 & 0 & - \\
\hline $\mathrm{NiO}$ & 10.97 & 1 & 37.99 & 41.660 & 11.707 & 5.954 & -234.2 & 1 & -211.6 & 17 \\
\hline$\alpha$-Quartz & 22.69 & 1 & 41.46 & 73.488 & 0.782 & 15.376 & -436.1 & 11 & -856.3 & 2 \\
\hline$\beta$-Quartz & 22.30 & 2 & 41.46 & 70.601 & 4.255 & 32.715 & -421.1 & 11 & -853.2 & 18 \\
\hline Corundum & 25.57 & 1 & 50.92 & 116.336 & 11.983 & 19.514 & -688.3 & 1 & -1582.2 & 1 \\
\hline Hematite & 30.28 & 2 & 87.49 & 84.429 & 92.839 & 1.987 & -511.0 & 2 & -745.3 & 2 \\
\hline Magnetite & 44.52 & 2 & 160.33 & 376.660 & -139.963 & 122.478 & -2242.1 & 2 & -1014.1 & 2 \\
\hline Kyanite & 44.21 & 3 & 82.42 & 177.000 & 24.849 & 29.564 & -1049.1 & 3 & -2445.8 & 4 \\
\hline Sillimanite & 50.02 & 3 & 95.77 & 169.439 & 28.903 & 25.623 & -1002.8 & 3 & -2440.7 & 4 \\
\hline Wollastonite & 39.79 & 2 & 81.67 & 102.236 & 28.447 & 13.443 & -605.9 & 2 & -1549.2 & 2 \\
\hline Enstatite & 31.35 & 2 & 66.32 & 118.248 & 11.159 & 20.280 & -699.6 & 1 & -1457.4 & 2 \\
\hline Ferrosilite & 32.99 & 4 & 95.82 & 116.495 & 15.201 & 16.159 & -686.3 & 12 & -1116.2 & 18 \\
\hline Fayalite & 46.15 & 5 & 152.13 & 156.620 & 35.066 & 15.619 & -920.4 & 2 & -1377.1 & 18 \\
\hline Diopside & 66.11 & 6 & 142.72 & 230.948 & 22.916 & 34.840 & -1361.3 & 13 & -3025.0 & 19 \\
\hline Hedenbergite & 67.85 & 7 & 173.59 & 214.116 & 48.359 & 24.698 & -1262.0 & 14,15 & -2677.7 & 20 \\
\hline Anorthite & 100.79 & 2 & 199.28 & 263.705 & 62.848 & 31.468 & -1556.7 & 2 & -4010.9 & 18 \\
\hline Grossular & 125.30 & 2 & 255.98 & 494.298 & 7.895 & 83.893 & -2912.6 & 4 & -6282.3 & 18 \\
\hline Andradite & 131.67 & 8 & 316.82 & 470.395 & 46.903 & 63.743 & -2765.6 & 16 & -5413.2 & 20 \\
\hline Almandine & 115.11 & 9 & 342.63 & 429.345 & 90.458 & 53.133 & -2532.8 & 9 & -4940.8 & 18 \\
\hline Pyrope & 113.27 & 10 & 266.27 & 452.332 & 44.807 & 65.538 & -2664.2 & 10 & -5936.4 & 20 \\
\hline
\end{tabular}

$S_{T}^{\circ}=S_{298}^{\circ}+\mathrm{A} \operatorname{Ln} T+\mathrm{B} 10^{-3} T+\mathrm{C} 10^{5} T^{-2}+\mathrm{D}$

1: Robie et al. 1979; 2: Robinson et al. 1982; 3: Robie and Hemingway 1984; 4: Anovitz and Essene 1987b; 5: Essene unpb1; 6: Levien and Prewitt 1981; 7: Cameron et al. 1973; 8: Huckenholz et al. 1974; 9: Metz et al. 1983; 10: Haselton and Newton 1980; 11: Hemingway 1987; 12: Bohlen et al. 1983; 13: Krupka et al. 1985a, 1985 b; 14: Bennington et al. 1984; 15: Haselton et al. 1987; 16: Robie et al. 1987; 17: Holmes et al. 1986; 18: Anovitz and Essene 1987a; 19: Sharp et al. 1986; 20: this study

Andradite $=$ Wollastonite + Magnetite $+\mathrm{O}_{2}$

$6 \mathrm{Ca}_{2} \mathrm{Fe}_{2} \mathrm{Si}_{3} \mathrm{O}_{12}=18 \mathrm{CaSiO}_{3}+4 \mathrm{Fe}_{3} \mathrm{O}_{4}+\mathrm{O}_{2}$

(Gustafson 1974),

Andradite + Magnetite + Quartz $=$ Hedenbergite $+\mathrm{O}_{2}$

$3 \mathrm{Ca}_{3} \mathrm{Fe}_{2} \mathrm{Si}_{3} \mathrm{O}_{12}+\mathrm{Fe}_{3} \mathrm{O}_{4}+9 \mathrm{SiO}_{2}=9 \mathrm{CaFeSi}_{2} \mathrm{O}_{6}+2 \mathrm{O}_{2}$

(Burton et al. 1982), and,

Andradite + Quartz $=$ Hedenbergite + Wollastonite $+\mathrm{O}_{2}$

$2 \mathrm{Ca}_{3} \mathrm{Fe}_{2} \mathrm{Si}_{3} \mathrm{O}_{12}+4 \mathrm{SiO}_{2}=4 \mathrm{CaFeSi}_{2} \mathrm{O}_{6}+2 \mathrm{CaSiO}_{3}+\mathrm{O}_{2}$

(Liou 1974).

The calculated position of these reactions in $\mathrm{fO}_{2}-T$ space at $2 \mathrm{kbar}$ (relative to $\mathrm{MH}$ ) are shown in Fig. 1, along with the calculated position of the NNO and FMQ buffers. The MH and FMQ buffers are calculated from data in Robinson et al. (1982, Table 1), and the NNO buffer is calculated from the solid state electrochemical measurements of Holmes et al. (1986, Table 1). All buffers were corrected for pressure and temperature using the expansivity and compressibility data in Table 2 .

Thermodynamic data for hematite, magnetite, and wollastonite are taken from Robinson et al. (1982), and data for andradite and hedenbergite are compiled from sources listed in Tables 1 and 2 . The $\Delta G_{298}^{\circ}$ for andradite was calculated from Reaction 11 using the experimental reversal of Huckenholz et al. (1974) (1 bar, $\left.1137 \pm 5^{\circ} \mathrm{C}\right)$ as a starting point, yielding $\Delta G_{298}^{\circ}(\mathrm{And})=$ $-5413.2 \mathrm{~kJ} / \mathrm{mol}$. If the reversal of Suwa et al. $\left(1976: 1 \mathrm{bar}, 1165^{\circ} \mathrm{C}\right)$ is used as a starting point, the free energy of andradite changes by $-0.3 \mathrm{~kJ}$. Use of the latter value for $\Delta G_{298}^{\circ}$ (And) shifts Reaction 12 to higher temperature, increasing the discrepancy between the experimental reversal for Reaction 12 and its calculated position (Fig. 1). Therefore we have used the reversal of Huckenholz et al. (1975) as the reference reaction for $\Delta G_{298}^{\circ}$ (And).

The experimental reversal at $800^{\circ} \mathrm{C}$ of Burton et al. (1982) for Reaction 13 was selected as the starting point for the calculation of $\Delta G_{298}^{\circ}(\mathrm{Hd})$, and the calculated position of Reaction 13 is in good agreement with the reversals at 600 and $700^{\circ} \mathrm{C}$ (Fig. 1). The position of Reaction 14 was calculated using the $\Delta G_{298}^{\circ}(\mathrm{Hd})$ $(-2677.7 \mathrm{~kJ} / \mathrm{mol})$ determined from these latter experimental constraints. Assuming that the reversals of Burton et al. (1982) are reliable, there is a discrepancy of $1.5 \log$ units between the calculated position of Reaction 14 and the experimental reversals of Liou (1974) (Fig. 1) that is not ascribable to errors in the thermodynamic data. The direction of the shift suggests that the synthetic andradite used in the experiments of Liou (1974) may be non-stoichiometric with possible substitutions of the nature $\mathrm{Fe}^{+2} \mathrm{Fe}^{+3}-\mathrm{CaFe}^{+3}$ or $(\mathrm{OH})_{4}^{-4}-\left(\mathrm{SiO}_{4}^{-4}\right)$. The reactants used in the experiments of Burton et al. (1982) were stoichiometric, but analyses of run products for Reaction 13 are not given. More thorough characterization of the run products for all experiments, or new experiments in the $\mathrm{Ca}$ $-\mathrm{Fe}-\mathrm{Si}-\mathrm{O}$ system, are required in order to resolve the discrepancy. Further calculation of reactions involving hedenbergite rest on the assumption of the choice of experimental constraints used here.

Using a slightly different experimental and thermodynamic data base, Robie et al. (1987) obtained values for $\Delta G_{298}^{\circ}$ (And) $=$ $-5414.8 \pm 5.5$ and $\Delta G_{298}^{\circ}(\mathrm{Hd})$ of $-2674.3 \pm 5.8 \mathrm{~kJ} / \mathrm{mole}$. The values differ from ours because we have included the effects of thermal expansion and compressibility in our calculation, and have started with a different thermodynamic data base. Helgeson et al. (1978) report values of $\Delta G_{298}^{\circ}$ (And) $=-5428.7 \mathrm{~kJ} / \mathrm{mol}$ and $\Delta G_{298}^{\circ}(\mathrm{Hd})=-2674.5 \mathrm{~kJ} / \mathrm{mol}$.

Volume and entropy data for pyrope are taken from Haselton and Westrum (1980) and Haselton and Newton (1980). The Gibbs energy of pyrope was calculated from experimental data on the reaction

Enstatite + Corundum $=$ Pyrope

$3 \mathrm{MgSiO}_{3}+\mathrm{Al}_{2} \mathrm{O}_{3}=\mathrm{Mg}_{3} \mathrm{Al}_{2} \mathrm{Si}_{3} \mathrm{O}_{12}$

(Gasparik and Newton 1984), using thermodynamic data for enstatite from Robinson et al. (1982) and data for corundum from Robie 
Table 2. Compressibility and thermal expansion data used in thermodynamic calculations

\begin{tabular}{|c|c|c|c|c|c|c|c|c|}
\hline Phase & $\mathrm{a}$ & $\mathrm{b}$ & Ref & $\mathrm{c}$ & d & $\mathrm{e}$ & $\mathrm{f}$ & Ref \\
\hline $\mathrm{Ni}$ & 0.535 & 0.900 & 21 & $1.092 \mathrm{E}-01$ & $4.207 \mathrm{E}-03$ & $1.663 \mathrm{E}-06$ & $-5.856 \mathrm{E}-10$ & 30 \\
\hline $\mathrm{NiO}$ & 0.600 & 1.000 & 22 & $-3.570 \mathrm{E}-02$ & $1.347 \mathrm{E}-03$ & $-2.295 \mathrm{E}-08$ & $-1.056 \mathrm{E}-10$ & 31 \\
\hline$\alpha$-Quartz & 4.300 & 24.000 & 21 & $1.944 \mathrm{E}-03$ & $3.274 \mathrm{E}-03$ & $2.876 \mathrm{E}-06$ & $6.922 \mathrm{E}-10$ & 2 \\
\hline$\beta$-Quartz & 1.776 & 0 & 21 & $3.861 \mathrm{E}-01$ & $1.983 \mathrm{E}-02$ & $2.562 \mathrm{E}-05$ & $1.044 \mathrm{E}-08$ & 2 \\
\hline Corundum & 0.380 & 0 & 21 & $-7.526 \mathrm{E}-02$ & $2.034 \mathrm{E}-03$ & $0.876 \mathrm{E}-06$ & $-3.150 \mathrm{E}-10$ & 30 \\
\hline Hematite & 0.509 & 0.454 & 2 & $9.682 \mathrm{E}-02$ & $3.870 \mathrm{E}-03$ & $1.056 \mathrm{E}-09$ & $-1.402 \mathrm{E}-12$ & 2 \\
\hline Magnetite & 0.560 & 0 & 2 & $-6.156 \mathrm{E}-02$ & $2.320 \mathrm{E}-03$ & $3.481 \mathrm{E}-06$ & $-1.486 \mathrm{E}-09$ & 2 \\
\hline Kyanite & 0.790 & 5.000 & 23 & $5.427 \mathrm{E}-02$ & $2.144 \mathrm{E}-03$ & $8.101 \mathrm{E}-10$ & $-3.296 \mathrm{E}-10$ & 32 \\
\hline Sillimanite & 0.788 & 4.810 & 23 & $1.964 \mathrm{E}-02$ & $7.618 \mathrm{E}-04$ & $1.476 \mathrm{E}-06$ & $-7.665 \mathrm{E}-10$ & 32 \\
\hline Wollastonite & 1.465 & 9.819 & 2 & $1.118 \mathrm{E}-01$ & $5.009 \mathrm{E}-03$ & $-4.166 \mathrm{E}-06$ & $1.554 \mathrm{E}-09$ & 2 \\
\hline Enstatite & 1.010 & 0 & 2 & $4.569 \mathrm{E}-03$ & -3.2922 E-04 & $5.928 \mathrm{E}-06$ & $-2.534 \mathrm{E}-09$ & 2 \\
\hline Ferrosilite & 0.990 & 0 & 24 & $9.590 \mathrm{E}-02$ & $3.822 \mathrm{E}-03$ & $5.737 \mathrm{E}-11$ & $2.778 \mathrm{E}-13$ & 4 \\
\hline Fayalite & 0.767 & 0.978 & 2 & $-2.810 \mathrm{E}-01$ & $1.017 \mathrm{E}-03$ & $3.881 \mathrm{E}-06$ & $-1.672 \mathrm{E}-09$ & 2 \\
\hline Diopside & 1.108 & 11.020 & $6,21,25$ & $9.535 \mathrm{E}-02$ & $4.005 \mathrm{E}-03$ & $-1.420 \mathrm{E}-06$ & $7.625 \mathrm{E}-10$ & 7 \\
\hline Hedenbergite & 2.117 & 31.313 & 26 & $-5.224 \mathrm{E}-02$ & $4.148 \mathrm{E}-03$ & $-4.245 \mathrm{E}-06$ & $2.999 \mathrm{E}-09$ & 7 \\
\hline Anorthite & 1.087 & 0 & 27 & $1.566 \mathrm{E}-01$ & $1.311 \mathrm{E}-03$ & $-8.876 \mathrm{E}-08$ & $2.075 \mathrm{E}-10$ & 2 \\
\hline Grossular & 0.721 & 3.200 & 2 & $-4.468 \mathrm{E}-02$ & $1.761 \mathrm{E}-03$ & $9.401 \mathrm{E}-07$ & $2.674 \mathrm{E}-10$ & 2 \\
\hline Andradite & 0.725 & 0 & 28 & $-4.731 \mathrm{E}-02$ & $2.107 \mathrm{E}-03$ & $5.732 \mathrm{E}-07$ & $7.252 \mathrm{E}-01$ & 30 \\
\hline Almandine & 0.571 & 0 & 4 & $4.541 \mathrm{E}-02$ & $1.654 \mathrm{E}-03$ & $1.231 \mathrm{E}-06$ & $-3.023 \mathrm{E}-10$ & 4 \\
\hline Pyrope & 0.137 & 2.650 & 29 & $4.876 \mathrm{E}-02$ & $2.084 \mathrm{E}-03$ & $8.206 \mathrm{E}-07$ & $-2.678 \mathrm{E}-10$ & 30 \\
\hline
\end{tabular}

$V_{298}^{P}=V_{298}^{\circ}\left(1-a P 10^{3}+b P^{2} 10^{6}\right), P$ kbar

$V_{T}^{\circ}=V_{298}^{\mathrm{o}}+V_{298}^{\circ} / 100\left[c+d T+e T^{2}+f T^{3}\right], T^{\circ} \mathrm{C}$,

2, 4, 6, 7: Table 1; 21: Birch 1966; 22: Hazen and Prewitt 1977; 23: Brace et al. 1969; 24: Bass and Weidner 1984; 25: Hazen and Finger 1981; 26: Vaidya et al. 1973; 27: Liebermann and Ringwood 1976; 28: Babuska et al. 1978; 29: Hazen and Finger 1978; 30: Skinner 1966; 31: Nielson and Leipold 1965; 32: Winter and Ghose 1979

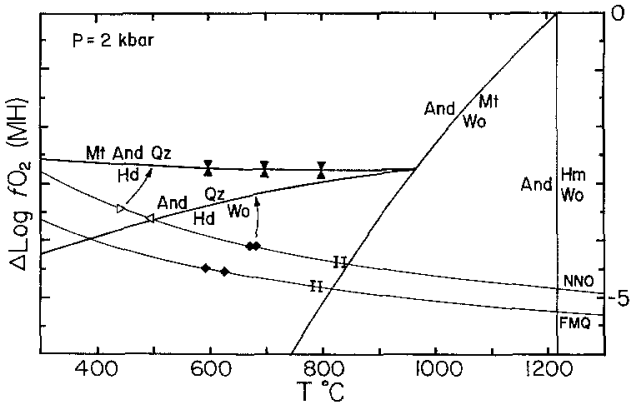

Fig. 1. $f \mathrm{O}_{2}-T$ equilibria at $2 \mathrm{kbar}$ in the system $\mathrm{Fe}-\mathrm{Si}-\mathrm{Ca}-\mathrm{O}$ (relative to $\mathrm{MH}$ buffer) that constrain $\Delta G_{298}^{\circ}$ of hedenbergite and andradite. Filled triangles: reversals of Burton et al. (1982) for Mt $+\mathrm{And}+\mathrm{Qz}=\mathrm{Hd}+\mathrm{O}_{2}$; open triangles reversals of Gustafson (1974) for $\mathrm{Mt}+\mathrm{And}+\mathrm{Qz}=\mathrm{Hd}+\mathrm{O}_{2}$ at $f \mathrm{O}_{2}$ defined by NNO buffer; vertical bars: reversals of Gustafson (1974) for $\mathrm{And}=\mathrm{Wo}+\mathrm{Mt}+\mathrm{O}_{2}$ at NNO and FMQ buffers; diamonds: reversals of Liou (1974) for $\mathrm{Hd}+\mathrm{Wo}=\mathrm{And}+\mathrm{Qz}+\mathrm{O}_{2}$ at $\mathrm{NNO}$ and FMQ buffers. Note disparity between calculated and experimental position of the latter reactions, denoted by arrows between reversals and reactions to which they correspond

et al. (1979). In the system $\mathrm{MgO}-\mathrm{Al}_{2} \mathrm{O}_{3}-\mathrm{SiO}_{2}$ (MAS), enstatite contains significant solid solution of $\mathrm{Mg}$-Tschermak's component $\left(\mathrm{Mg}_{0.5} \mathrm{AlSi}_{0.5} \mathrm{O}_{3}\right)$ (Boyd and England 1964; Hensen and Essene 1971; Anastasiou and Seifert 1972; MacGregor 1974; Danckwerth and Newton 1978; Lane and Ganguly 1980; Perkins and Newton 1980; Perkins et al. 1981; Perkins 1983). In order to calculate the location of the end member Reaction (15) one must correct for the reduction in enstatite activity. Aranovich and Kosyakova (1987) have recently published activity-composition relations for orthopyroxene that are based on experimental equilibria in the MAS and FMAS systems. For the range of aluminum contents encountered in the above experimental studies the model of Aranovich and Kosyakova (1987) yields activity coefficients for the $\mathrm{MgSiO}_{3}$ component in enstatite-Mg-Tschermak's solid solutions $\left.\left(\gamma_{\mathrm{Mgx}}^{\mathrm{Opx}}\right)_{3}\right)$ that are slightly less than one, suggesting only slight departures from ideality. However, the difference between the ideal model and the model of Aranovich and Kosyakova (1987) may yield significant differences in the Gibbs energy of pyrope because reactions involving pyrope and enstatite are extremely sensitive to changes in pressure. We have employed the latter model in the calculations to follow.

Using the midpoint of the reversal for Reaction 15 (Gasparik and Newton $1984,850^{\circ} \mathrm{C}$ and $\left.16.25 \pm 0.25 \mathrm{kbar}, X_{\mathrm{MgTs}}^{\mathrm{En}}=0.06\right)$ as a starting point for the calculation, the shift in position of Reaction 15 due to orthopyroxene solid solution was calculated from the relation

$R T \ln \left(K_{2} / K_{1}\right)=\int_{P_{1}}^{P_{2}} \Delta V d P$

where $K_{2}=1$ for the position of the corrected reversal,

$$
K_{1}=\left(1 / a_{\mathrm{MgSiO}}^{\mathrm{Opx}}\right)^{3},
$$

and pyrope, sillimanite and quartz are assumed to be pure phases. For these calculations we have followed the convention of Hensen and Essene (1971) and Aranovich and Kosyakova (1987) by writing the formula of enstatite and $\mathrm{Mg}$-Tschermak based on 2 cations (see Appendices I and II). The location of Reaction 15, adjusted to pure enstatite, is at $12.7 \mathrm{kbar}, 850^{\circ} \mathrm{C}$, and serves as the starting point for calculation of the Gibbs energy of pyrope. The calculated value of $\Delta G_{298}^{\circ}$ (Reaction 15) is $18.1 \mathrm{~kJ} / \mathrm{mol}$, yielding $\Delta G_{298}^{\circ}(\mathrm{Py})$ $=-5936.4 \mathrm{~kJ} / \mathrm{mol}$. As in deriving the Gibbs energy of hedenbergite, the Gibbs energy for pyrope is dependent on our choice of experiments and Gibbs free energies for enstatite and corundum.

Wood and Holloway (1984) present an analysis of equilibria in the CMAS system, deriving an $\Delta H_{1000}^{\circ}$ for pyrope (relative to oxides) of $-84.9 \mathrm{~kJ} / \mathrm{mol}\left(S_{1000 \mathrm{~K}}=777.8 \mathrm{~J} / \mathrm{mol}\right.$, Haselton and Newton 1980). Using enthalpy and entropy data for the oxides (Robie et al. 1979), this yields $\Delta G_{1000}^{\circ}$ (Py) for the study of Wood and 

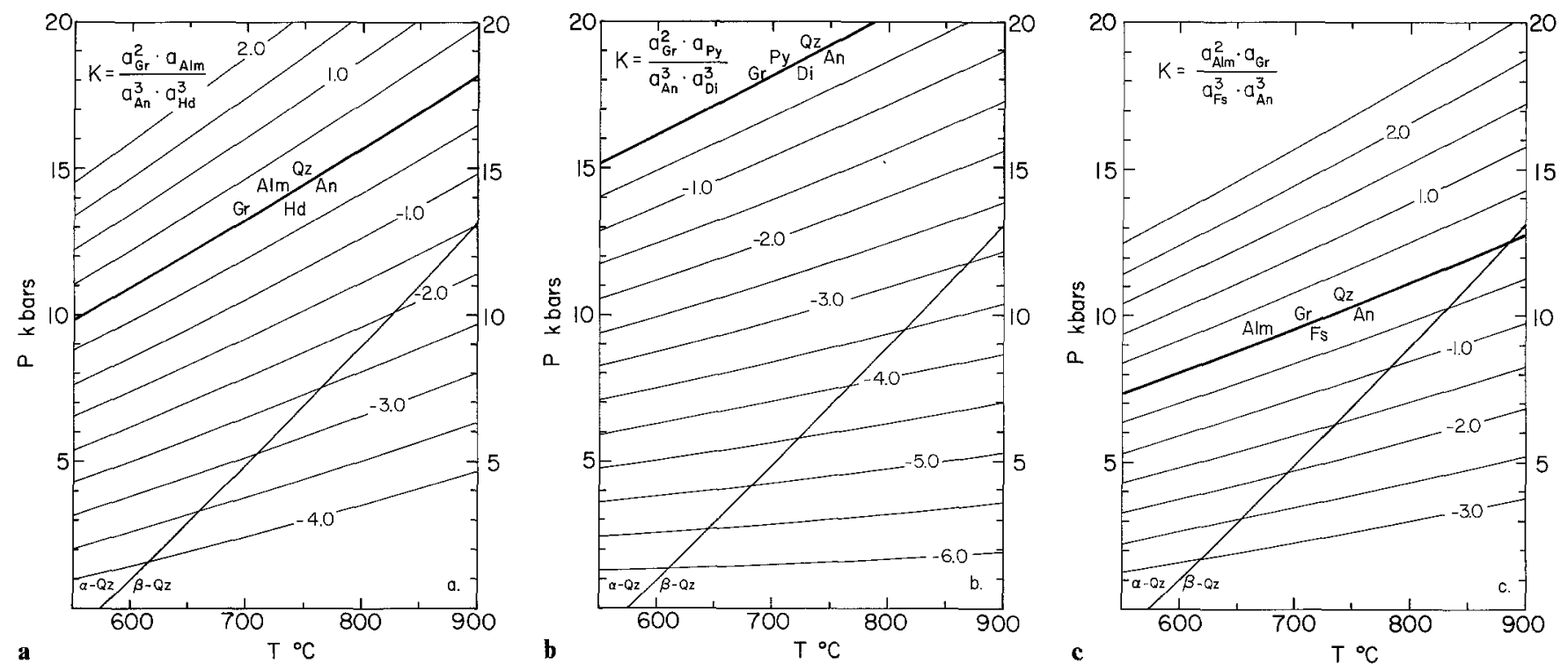

Fig. 2a-c. Calculated position and values of $\log _{10} K$ for Reactions 1 through $3 ; \mathbf{a}$ HD barometer; b DI barometer; $\mathbf{c}$ FS barometer

Holloway of $-87.8 \mathrm{~kJ} / \mathrm{mol}$, in fair agreement with the value derived in this study $\left(\Delta G_{1000}^{\circ}=-83.4 \mathrm{~kJ} / \mathrm{mol}, \Delta H_{1000}^{\circ}=-79.3 \mathrm{~kJ} / \mathrm{mol}\right)$.

Newton (1987) has re-evaluated experiments in the system $\mathrm{MgO}-\mathrm{Al}_{2} \mathrm{O}_{3}-\mathrm{SiO}_{2}$ that constrain $\Delta H_{298}^{\circ}$ and $\Delta G_{298}^{\circ}$ of pyrope and enstatite. Based on analysis of the available experimental and thermochemical data base Newton (1987) obtains values for $\Delta H_{298}^{\circ}(\mathrm{Py})$ and $\Delta H_{298}^{\circ}(\mathrm{En})$ (relative to oxides) of -74.2 and $-32.7 \mathrm{~kJ} / \mathrm{mol}$, respectively. Combined with entropy data for these phases the calculated values of $\Delta G_{298}^{\circ}$ (oxides) are -77.2 and -32.1 , respectively. Our values of $A G_{298}^{\circ}$ are in very good agreement with those of Newton (1987): -77.7 and -31.9 for pyrope and enstatite, respectively. The same experimental data base was used in both studies, but different values of $S_{298}^{\circ}$ for enstatite were used and the mechanics of calculating the location of the equilibria using EQUILI differ slightly from the method used by Newton (1987).

Other thermodynamic compilations yield Gibbs free energies for enstatite that are in good agreement with the values used in this study. Berman et al. (1986) give a value for $\Delta G_{298}^{\circ}(E n)=$ $-1458.5 \mathrm{~kJ} / \mathrm{mol}$, and Helgeson et al. (1978) report a value of $-1459.9 \mathrm{~kJ} / \mathrm{mol}$.

The free energies of pyrope and enstatite have also been evaluated by fitting the experimentally reversed equilibrium

Enstatite + Sillimanite $=$ Pyrope + Quartz

$3 \mathrm{MgSiO}_{3}+\mathrm{Al}_{2} \mathrm{SiO}_{5}=\mathrm{Mg}_{3} \mathrm{Al}_{2} \mathrm{Si}_{3} \mathrm{O}_{12}+\mathrm{SiO}_{2}$

(Hensen and Essene 1971; Perkins 1983), with various estimates of the high temperature heat capacity of pyrope. There are significant disparities between the experiments of Hensen and Essene (1971) and Perkins (1983) on Reaction 16 at 1150 and $1300^{\circ} \mathrm{C}$, and among the possible high temperature extrapolations for the entropy of pyrope in the temperature range of the experiments (Haselton and Newton 1980; Robinson and Haas 1983; Berman and Brown 1985). However, both experimental data sets (adjusted for the Al content of the orthopyroxene using the methods discussed above) and the various heat capacity expressions converge at $1000^{\circ} \mathrm{C}$ (Moecher 1988). The thermodynamic data used in the present study for pyrope (with the heat capacity of pyrope from Haselton and Newton 1980) and enstatite are in very good agreement with both sets of experiments at $1000^{\circ} \mathrm{C}$. More complete characterization of synthetic reactants and experimental products for Reaction 16 , or high temperature $(>1200 \mathrm{~K})$ calorimetry on pyrope are needed in order to resolve the discrepancy at temperatures above the $1000^{\circ} \mathrm{C}$ reversals.

\section{Geobarometry}

\section{Clinopyroxene barometers}

The positions of Reactions 1,2 and 3 were calculated using 1 bar, $298 \mathrm{~K}$ as a starting point (Figs. $2 \mathrm{a}-2 \mathrm{c}$ ). The clinopyroxene reactions have average slopes $(\triangle P / \Delta T)$ of $23(\mathrm{HD})$ and 20 bar $/{ }^{\circ} \mathrm{C}$ (DI). These slopes are not as low as Reaction $3\left(14.5 \mathrm{bar} /{ }^{\circ} \mathrm{C}\right)$, but are still useful for geobarometry, with the $\mathrm{HD}$ barometer having the greatest temperature dependency of the three barometers. The calculated slopes become less steep at lower pressure and more negative values of $\log _{10} K$ (Fig. 2), particularly for the FS and DI barometers. An uncertainty of $5 \mathrm{~kJ}$ in the value of $\Delta G_{298}^{\circ}(\mathrm{rxn})$ results in an uncertainty of approximately $0.7 \mathrm{kbar}$ for both Reactions 1 and 2 . Uncertainties of $5 \mathrm{~kJ}$ in the $\Delta G_{298}^{\circ}$ for any phase involved in the reaction will yield an uncertainty of $0.7 \mathrm{kbar}$ per mole of that phase in Reactions 1 and 2.

\section{Activity models}

Application of these equilibria to natural systems requires consideration of the reduction in activity of end member components due to solid solutions in plagioclase, garnet, orthopyroxene, and clinopyroxene. Included in Figs. $2 \mathrm{a}, 2 \mathrm{~b}$, and $2 c$ are the calculated positions for values of $\log _{10}$ of the equilibrium constant $K$ for each reaction. For example $K$ is defined for Reaction 1 by the relation:

$$
\begin{aligned}
K= & \left(a_{\mathrm{Ca}_{3} \mathrm{Al}_{2} \mathrm{Si}_{3} \mathrm{O}_{12}}^{\mathrm{Gt}}\right)^{2} a_{\mathrm{Fe}_{3} \mathrm{Al}_{2} \mathrm{Si}_{3} \mathrm{O}_{12} /} / \\
& \left(a_{\mathrm{CaAl}_{2} \mathrm{Si}_{2} \mathrm{O}_{8}}\right)^{3}\left(a_{\mathrm{CaFeSi}_{2} \mathrm{O}_{6}}^{\mathrm{Cpx}^{3} .}\right.
\end{aligned}
$$

Variations in $\log _{10} K$ with pressure were calculated from the relation:

$$
R T \ln \left(K_{2} / K_{1}\right)=\Delta G_{T_{2}}^{P_{2}}-\Delta G_{T_{2}}^{P_{1}}=\int_{P_{1}}^{P_{2}} \Delta V d P
$$

Given appropriate activity models for plagioclase, garnet, and pyroxene, the equilibrium constant can be calculated from chemical analyses of the coexisting phases, and with 

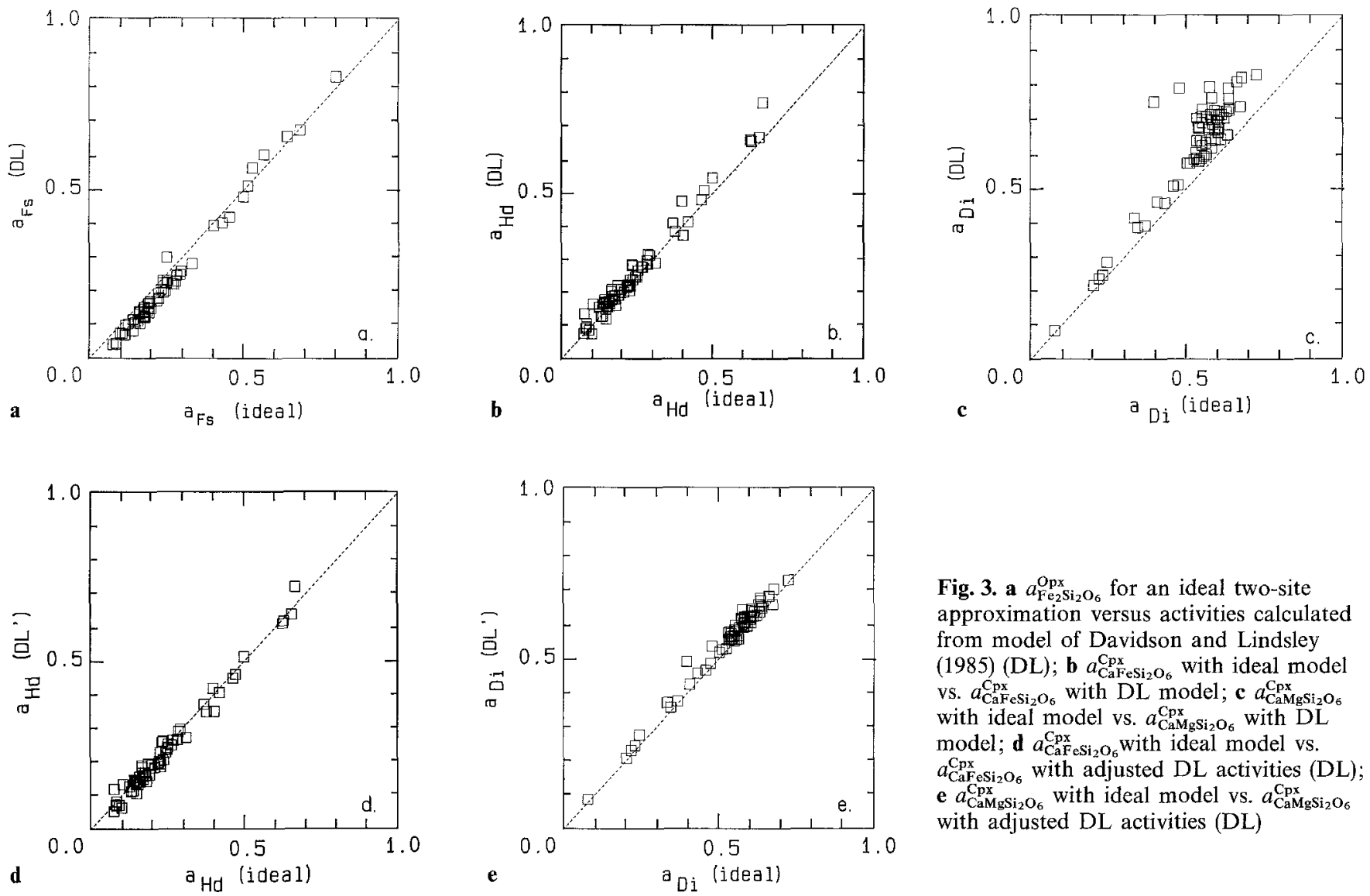

Fig. 3. a $a_{\mathrm{Fe}_{2} \mathrm{Si}_{2} \mathrm{O}_{6}}^{\mathrm{Opx}}$ for an ideal two-site approximation versus activities calculated from model of Davidson and Lindsley (1985) (DL); b $a_{\mathrm{CaFeSi}_{2} \mathrm{O}_{6}}^{\mathrm{Cpx}}$ with ideal model

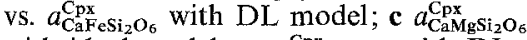

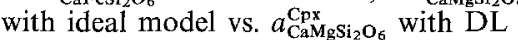
model; $\mathbf{d} a_{\mathrm{CaF}_{2} \mathrm{Ci}_{2} \mathrm{O}_{6}}$ with ideal model vs. $a_{\mathrm{CaFeSi}} \mathrm{Cpx}_{6}$ with adjusted DL activities (DL); e $a_{\mathrm{CaMgSi}_{2} \mathrm{O}_{6}}^{\mathrm{C} \mathrm{CS}_{2}}$ with ideal model vs. $a_{\mathrm{CaMgSi}_{2} \mathrm{O}_{6}}^{\mathrm{Cpx}}$ with adjusted DL activities (DL)

an estimate of temperature the pressure can be read from Fig. 3.

The activity models for plagioclase, garnet, or pyroxene will ultimately limit the accuracy and precision of a geobarometer. The models of Newton et al. (1980) or Orville (1972) for plagioclase, Perkins (1979), Newton and Haselton (1981), or Ganguly and Saxena (1984) for garnet, and an ideal two site approximation (e.g., Wood and Banno, 1973) for pyroxenes are typically selected by most workers. For this study the plagioclase activity model of Newton et al. (1980) (Appendix II) was used in evaluation of the geobarometers. At $700^{\circ} \mathrm{C}$ and constant garnet and pyroxene activities, this latter plagioclase activity model yields slightly lower pressures (on the order of $0.1 \mathrm{kbar}$ ) than that of Orville (1972).

The quaternary garnet mixing model of Ganguly and Saxena (1984) with modified values for $\mathrm{Ca}-\mathrm{Fe}$ mixing parameters (Anovitz and Essene, 1987a) was used to calculate the activity of $\mathrm{Ca}_{3} \mathrm{Al}_{2} \mathrm{Si}_{3} \mathrm{O}_{12}, \mathrm{Fe}_{3} \mathrm{Al}_{2} \mathrm{Si}_{3} \mathrm{O}_{12}$, and $\mathrm{Mg}_{3} \mathrm{Al}_{2} \mathrm{Si}_{3} \mathrm{O}_{12}$ in garnet, and to calculate the position of the FS reaction (Reaction 3 ). The derivation of these parameters are discussed by Anovitz and Essene (1987 a), and analytical expressions for calculating activities are outlined in Appendix II. The model used here typically yields $\mathrm{Ca}_{3} \mathrm{Al}_{2} \mathrm{Si}_{3} \mathrm{O}_{12}$ and $\mathrm{Fe}_{3} \mathrm{Al}_{2} \mathrm{Si}_{3} \mathrm{O}_{12}$ activities 1 to $5 \%$ greater than values obtained from the original formulation of Ganguly and Saxena (1984).

Activity coefficients for $\mathrm{Mg}_{3} \mathrm{Al}_{2} \mathrm{Si}_{3} \mathrm{O}_{12}$ in garnet $\left(\gamma_{\mathrm{Mg}}^{\mathrm{Gt}}\right)$ obtained from the model of Ganguly and Saxena (1984) (GS) are significantly greater than those obtained from the model of Haselton and Newton (1980: HN). For a garnet of composition $\mathrm{Alm}_{50} \mathrm{Py}_{25} \mathrm{Gr}_{25}$ at $700^{\circ} \mathrm{C}$, $\gamma_{\mathrm{Mg}}^{\mathrm{Gi}}(\mathrm{GS})=1.7$ and $\gamma_{\mathrm{Mg}}^{\mathrm{Gt}}(\mathrm{HN})=1.3$. This difference is due to the sign for the ternary constants as discussed by Ganguly and Saxena (1984, p 94, eq 16). If the sign of the ternary constant in the expression for $\gamma_{\mathrm{Mg}}^{\mathrm{Gt}}$ is changed from that given in Ganguly and Saxena (1984), one obtains similar values for $\gamma_{\mathrm{Mg}}^{\mathrm{Gt}}$ for the two models. This discrepancy needs further evaluation. In general, use of the GS model as it now stands yields significantly lower pressures than the HN model for the DI barometer, all other factors being equal.

Chatillon-Colinet et al. (1983) proposed that an ideal mixing approximation for $\mathrm{Mg}-\mathrm{Fe}$ orthopyroxenes is consistent with solution calorimetric data on orthopyroxene solid solutions. Therefore the activity of $\mathrm{FeSiO}_{3}$ in orthopyroxene was calculated using the ideal model of Wood and Banno (1973) (Appendix II). Davidson and Lindsley (1985) have modeled the phase equilibria of quadrilateral pyroxenes in order to derive a pyroxene activity model. Although Davidson and Lindsley do not present an explicit analytical formulation for activity coefficients similar to garnet and plagioclase, we obtained a computer program (PM Davidson pers comm 1987) that calculates activities of $\mathrm{Fe}_{2} \mathrm{Si}_{2} \mathrm{O}_{6}$, $\mathrm{Mg}_{2} \mathrm{Si}_{2} \mathrm{O}_{6}, \mathrm{CaFeSi}_{2} \mathrm{O}_{6}$, and $\mathrm{CaMgSi}_{2} \mathrm{O}_{6}$ for quadrilateral pyroxene. The pyroxene projection scheme of Lindsley (1983) was used to calculate mole fractions of Wo, En and Fs, the components upon which the activity model of Davidson and Lindsley (1985) is calculated. The pyroxene activity model of Davidson and Lindsley (1985) yields activities of $a_{\mathrm{Fe}_{2} \mathrm{Si}_{2} \mathrm{O}_{6}}^{\mathrm{Opx}}$ that are similar to or only slightly less than ideal two site activities calculated with the Wood and Banno (1973) model (Fig. 3a).

Activities of $\mathrm{CaFeSi}_{2} \mathrm{O}_{6}$ and $\mathrm{CaMgSi}_{2} \mathrm{O}_{6}$ were also cal- 
Table 3. Sources of analytical data on $\mathrm{Gt}-\mathrm{Cpx}-\mathrm{Opx}-\mathrm{Pg}-\mathrm{Qz}$ assemblages and quoted aluminosilicate occurrences used to evaluate geobarometers of this study

\begin{tabular}{|c|c|c|c|c|}
\hline Terrane & Samples & Ref & ALS $^{\mathrm{a}}$ & $T^{\circ} \mathrm{C} / P \mathrm{kbar}^{\mathrm{b}}$ \\
\hline \multicolumn{5}{|l|}{ Grenville Province } \\
\hline $\begin{array}{l}\text { Parry Sound Ont } \\
\text { Otter Lake Que }\end{array}$ & $\begin{array}{l}\text { S3B 015B S10B M65 S32 S86E33 } \\
\text { A12 DL2 }\end{array}$ & $\begin{array}{l}1 \\
2\end{array}$ & $\begin{array}{l}\text { Sil } \\
\text { Sil }\end{array}$ & $\begin{array}{l}800 /<9.8 \\
700 /<7.8\end{array}$ \\
\hline $\begin{array}{l}\text { Adirondack Mts } \\
\text { Highlands }\end{array}$ & $\begin{array}{l}\text { BM2 BM } 13 \text { ET15 ET24 LL6 MM4 MM18 PH4 SL5 SL26 SR } 31 \\
\text { W9 } \\
74 \text { C } 248 \text { B }\end{array}$ & $\begin{array}{l}3 \\
4\end{array}$ & Sil & $\begin{array}{l}800 /<9.8 \\
700 /<78\end{array}$ \\
\hline $\begin{array}{l}\text { Lowlands } \\
\text { Pikwitonei Belt }\end{array}$ & $\begin{array}{l}74 \mathrm{C} 248 \mathrm{~B} \\
\mathrm{~A} 41 \mathrm{C} 104 \mathrm{D} 50 \mathrm{D} 110 \mathrm{E} 18\end{array}$ & 4 & $\begin{array}{l}\text { Sil } \\
\text { Sil }\end{array}$ & $\begin{array}{l}700 /<7.8 \\
800 /<9.8\end{array}$ \\
\hline $\begin{array}{l}\text { India } \\
\text { Sargur Belt } \\
\text { Karnataka }\end{array}$ & $\begin{array}{l}\text { S33 } \\
\text { S3 S4 } \\
113 E \text { GN4A } \\
\text { DT MB GV2 }\end{array}$ & $\begin{array}{l}6 \\
7 \\
8 \\
9\end{array}$ & $\mathrm{Ky} / \mathrm{Sil}$ & $700 /<7.8$ \\
\hline $\begin{array}{l}\text { Nilgiri Hills } \\
\text { Mysore } \\
\text { Bengal }\end{array}$ & $\begin{array}{l}332352680 \\
\text { K21 } \\
\text { SM4B SM44B }\end{array}$ & $\begin{array}{l}10 \\
11 \\
12\end{array}$ & $\begin{array}{l}\text { Sil } \\
\text { Sil }\end{array}$ & $\begin{array}{l}750 /<8.8 \\
700 /<7.8\end{array}$ \\
\hline Furua Complex & MF 283.3 MF 268.1 WE 322.3 ZC.8 DMa 40 C247.1 C 311.1 C352.2 & 13 & $\mathrm{Ky} / \mathrm{Sil}$ & $800 / 9.8$ \\
\hline Westchester PA & $74-67,-71,-207 \mathrm{~A},-322 \mathrm{C}$ & 14 & Ky & $650 />6.8$ \\
\hline Wind R. Range WY & A 22 & 15 & Sil & $700 /<7.8$ \\
\hline SW Minnesota & $\mathrm{DM} 4 \mathrm{C} 2$ & 16 & Sil & $700 /<7.8$ \\
\hline Lesotho & LT2 & 17 & & \\
\hline Oaxacan Complex & 160762527716976 & 18 & Sil & $730 /<8.3$ \\
\hline \multicolumn{5}{|l|}{ West Greenland } \\
\hline $\begin{array}{l}\text { Buksefjorden } \\
\text { Isortoq }\end{array}$ & $\begin{array}{l}174087 \\
174102 \\
8858991141\end{array}$ & $\begin{array}{l}19 \\
20\end{array}$ & $\begin{array}{l}\text { Sil } \\
\text { Ky/Sil }\end{array}$ & $\begin{array}{l}800 /<9.8 \\
600 / 6.3\end{array}$ \\
\hline Finnish Lapland & 47III 66II & 21 & Sil & $750 /<8.8$ \\
\hline Doubtful Sound & 3646136468 & 22 & & \\
\hline Broken Hill & 91110770 & 23 & Sil & $800 /<9.8$ \\
\hline
\end{tabular}

a $A L S=$ aluminosilicate: $K y=$ kyanite, Sil $=$ Sillimanite.

${ }^{b}$ Quoted $T$ with $P$ constraint.

1: Moecher (1988); 2: Perkins (1979); 3: Bohlen (1979); 4: Stoddard (1976); 5: Paktunc and Baer (1986); 6: Janardhan and Gopalkrishna (1983); 7: Srikantappa et al. (1985); 8: Janardhan et al. (1982); 9: Hansen et al. (1984); 10: Harris et al. (1982); 11: Devaraju and Coolen (1983); 12: Bhattacharya and Mukherjee (1987); 13: Coolen (1980); 14: Wagner and Srogi (1987); 15: Sharp (1988); 16: Moecher (1984); 17: Griffen et al. (1979); 18: Mora and Valley (1985); 19: Wells (1977); 20: Glassley and Sorensen (1980); 21: Hörmann et al. (1980); 22: Oliver (1977); 23: Phillips (1978)

culated using a modified ideal model, in comparison with the model of Davidson and Lindsley (1985). Ideal $\mathrm{CaFeSi}_{2} \mathrm{O}_{6}$ activities were approximated by the relationship

$a_{\mathrm{CaFeSi}_{2} \mathrm{O}_{6}}^{\mathrm{Cpx}}=\left[X_{\mathrm{Ca}}^{\mathrm{M} 2}\right]\left[X_{\mathrm{Fe}^{2+}}^{\mathrm{M} 1}\right]$

where $X_{\mathrm{Fe}^{2+}}^{\mathrm{M} 1}=\mathrm{Fe}^{2}-(1-\mathrm{Ca}-\mathrm{Na}-\mathrm{Mn}), X_{\mathrm{Ca}}^{\mathrm{M} 2}=\mathrm{Ca}$, and $\mathrm{Ca}$, $\mathrm{Na}, \mathrm{Mn}$, and $\mathrm{Fe}^{2+}$ are the number of atoms of the respective cations. Pyroxene analyses taken from the literature are renormalized to four cations, and values of ferric and ferrous iron were calculated from charge balance and stoichiometry. Analyses taken from the literature were of varying quality, and not all of these pyroxenes were analyzed for $\mathrm{Na}$, which usually occurs in significant quantities in high grade clinopyroxenes. Failure to analyze for $\mathrm{Na}$ will affect the calcula- tion of $\mathrm{Fe}^{2+}$ and $\mathrm{Fe}^{3+}$, and ultimately the value of $X_{\mathrm{Fe}^{2+}}^{\mathrm{M} 2}$. Ideal $\mathrm{CaMgSi}_{2} \mathrm{O}_{6}$ activities were calculated as

$a_{\mathrm{CaMgSi}_{2} \mathrm{O}_{6}}^{\mathrm{Cpx}}=\left[X_{\mathrm{Ca}}^{\mathrm{M} 2}\right]\left[X_{\mathrm{Mg}}^{\mathrm{M} 1}\right]$.

where $X_{\mathrm{Ca}}^{\mathrm{M} 2}=\mathrm{Ca}$ and $X_{\mathrm{Mg}}^{\mathrm{M} 1}=\mathrm{Mg}$, based on a 4-cation pyroxene formula. The clinopyroxene model is based on crystal chemical observations on igneous pyroxenes that iron and magnesium do not mix ideally on the M1 and M2 sites, with iron showing a greater tendency relative to magnesium to partition into the M2 site (Cameron and Papike 1980; Dal Negro et al. 1982). Although there are no cation partitioning data on granulite facies augites, one might predict that the ordering would be even more pronounced in granulite facies augites compared to igneous augites, as tempera- 
Table 4. Comparison of quoted pressures from other $\mathrm{Opx}-\mathrm{Pg}-\mathrm{Gt}-\mathrm{Qz}$ barometers with orthopyroxene and clinopyroxene barometers of this study (using ideal pyroxene activities). References as in Table 3 . nd $=$ pressure not determined

\begin{tabular}{|c|c|c|c|c|c|c|c|c|}
\hline Locality & REF & BWB-FS & PC-FS & MAE-FS & NP-EN & PC-EN & MAE-HD & MAE-DI \\
\hline Parry Sound & 1 & nd & nd & $7.5-11.7$ & nd & nd & $8.1-12.8$ & $8.2-12.0$ \\
\hline Otter Lake & 2 & $8.1,<8.4$ & $8.0,<7.5$ & $8.4,<8.5$ & $6.6,<8.1$ & $9.7,<9.1$ & $8.5,<7.9$ & $7.8,<7.2$ \\
\hline Adir. High. & 3 & $7.1-8.2$ & $7.1-8.6$ & $6.5-8.8$ & $8.5-9.9$ & $10.4-11.5$ & $5.8-9.5$ & $7.4-13.1$ \\
\hline Adir. Low. & 4 & 6.6 & nd & 6.4 & 6.1 & nd & 5.6 & 6.1 \\
\hline Pikwitonei ${ }^{a}$ & 5 & $6.6-9.2$ & $7.9-11.7$ & $6.6-9.1$ & $7.1-9.5$ & $11.1-12.8$ & $5.3-9.4$ & $4.7-8.3$ \\
\hline Sargur ${ }^{a}$ & $\begin{array}{l}6 \\
7\end{array}$ & $\begin{array}{l}\text { nd } \\
\text { nd }\end{array}$ & $\begin{array}{l}\text { nd } \\
\text { nd }\end{array}$ & $\begin{array}{l}9.0 \\
10.5,10.5\end{array}$ & $\begin{array}{l}9.0 \\
9.1,9.1\end{array}$ & $\begin{array}{l}\text { nd } \\
\text { nd }\end{array}$ & $\begin{array}{l}10.1 \\
9.7,10.1\end{array}$ & $\begin{array}{l}8.3 \\
7.0,7.1\end{array}$ \\
\hline Karnataka $^{a}$ & $\begin{array}{l}8 \\
9\end{array}$ & $\begin{array}{l}9.0,9.2 \\
\text { nd }\end{array}$ & $\begin{array}{l}10.0,9.5 \\
\text { nd }\end{array}$ & $\begin{array}{l}9.5,10.4 \\
8.4-9.1\end{array}$ & $\begin{array}{l}8.3,9.5 \\
9.1,9.1\end{array}$ & $\begin{array}{l}9.4,9.8 \\
\text { nd }\end{array}$ & $\begin{array}{l}8.7,10.7 \\
8.0-8.7\end{array}$ & $\begin{array}{l}8.1,8.8 \\
7.0-7.7\end{array}$ \\
\hline Nilgiri $^{a}$ & 10 & nd & nd & $9.0-10.2$ & $6.9-8.8$ & nd & $9.1-10.0$ & $8.5-9.5$ \\
\hline Mysore $^{a}$ & 11 & nd & nd & 12.1 & 9.9 & nd & 11.8 & 9.5 \\
\hline Bengal $^{a}$ & 12 & nd & nd & $7.5,7.2$ & $6.2,6.3$ & nd & $8.9,7.9$ & $7.9,7.6$ \\
\hline Furua Complex & 13 & $9.6-11.4$ & $9.9-12.1$ & $10.1-12.6$ & $9.4-12.7$ & $9.8-11.6$ & $9.9-12.8$ & $7.4-10.2$ \\
\hline Westchester ${ }^{a}$ & 14 & $8.9-9.6$ & $9.8-10.8$ & $9.6-10.0$ & $5.6-9.4$ & $9.1-12.3$ & $9.9-11.5$ & $7.3-8.8$ \\
\hline Wind R Range ${ }^{a}$ & 15 & 5.0 & nd & 5.3 & nd & nd & 6.1 & 8.2 \\
\hline Minn R Valley ${ }^{\mathrm{a}}$ & 16 & nd & nd & 6.0 & nd & nd & 5.8 & 7.0 \\
\hline Lesotho & 17 & nd & nd & 11.8 & 10.1 & nd & 12.6 & 10.0 \\
\hline Oaxaca Complex ${ }^{\mathrm{a}}$ & 18 & $6.3-7.3$ & nd & $7.3-8.0$ & $7.5-7.8$ & nd & $7.0-8.0$ & $6.7-8.0$ \\
\hline Buksefjorden & 19 & $8.3,7.4$ & $9.3,8.5$ & $9.5,8.7$ & $7.6,7.5$ & $9.2,8.6$ & $11.6,7.4$ & $9.1,4.8$ \\
\hline Isortoq & 20 & nd & nd & $7.7,7.7$ & $7.6,8.3$ & nd & $8.1,8.7$ & $7.4,7.6$ \\
\hline Finnish Lapland & 21 & $7.6, \mathrm{nd}$ & $7.9,8.0$ & $9.0,9.0$ & 7.3, nd & $9.1,9.1$ & $8.8,9.6$ & $8.5,9.2$ \\
\hline Doubtful Sound & 22 & $11.2,9.6$ & $11.2,12.7$ & $13.0,11.8$ & 12.1 & $12.5,12.7$ & $16.1,15.4$ & $14.0,12.6$ \\
\hline Broken Hill & 23 & nd & nd & $4.5,4.0$ & nd & nd & $3.0,2.5$ & $3.8,3.0$ \\
\hline
\end{tabular}

${ }^{a}$ pressure quoted by reference for a particular locality otherwise pressure quoted by authors of calibration.

$N P$ : Newton and Perkins (1982) $\mathrm{Mg}-\mathrm{Opx}+\mathrm{Pg}=\mathrm{Gt}+\mathrm{Qz}$ barometer

$B W B$ : Bohlen, Wall and Boettcher (1983a) $\mathrm{Fe}-\mathrm{Opx}+\mathrm{Pg}=\mathrm{Gt}+\mathrm{Qz}$ barometer

$P C$ : Perkins and Chipera (1985) $\mathrm{Fe}-\mathrm{Opx}$ and $\mathrm{Mg}-\mathrm{Opx}+\mathrm{Pg}=\mathrm{Gt}+\mathrm{Qz}$ barometer

$M A E$ : Moecher, Anovitz and Essene, this study, FS, HD, and DI barometers

tures are lower and cooling histories are likely to be slower for the former. Single crystal refinements and Mössbauer studies of homogeneous natural pyroxenes from the granulite facies are needed to evaluate this assumption further.

Activities of $\mathrm{CaFeSi}_{2} \mathrm{O}_{6}$ in $\mathrm{Cpx}\left(a_{\mathrm{CaFeSi}_{2} \mathrm{O}_{6}}^{\mathrm{Cpx}_{2}}\right.$ calculated with the model of Davidson and Lindsley (1985) yield $a_{\mathrm{CaFeSi}}^{\mathrm{Cpx} \mathrm{O}_{6}}$ that are usually similar to or slightly greater than values obtained using the ideal approximation (Fig. $3 \mathrm{~b}$ ). The values for $a_{\mathrm{CaMgSi}_{2} \mathrm{O}_{6}}^{\mathrm{Cpx}}$ calculated from the model of $\mathrm{Da}$ vidson and Lindsley (1985) are generally greater than ideal activities (Fig. $3 \mathrm{c}$ ). The scatter in $a_{\mathrm{CaMgSi}_{2} \mathrm{O}_{6}}^{\mathrm{Cpx}}$ is an artifact of the projection scheme used to correct natural compositions to those appropriate for the activity model. The effect of subtracting non-quadrilateral components (mainly $\mathrm{Al}$, $\mathrm{Na}$, and $\mathrm{Fe}^{3+}$ in granulite facies pyroxenes) in the projection scheme is to overestimate the amount of quadrilateral pyroxene components, and this projection scheme is not strictly valid for clinopyroxenes with a large fraction of nonquadrilateral components (Lindsley 1983). The greatest departure from quadrilateral space is for aluminous and sodic pyroxenes in granulites from Doubtful Sound, N.Z., in granulite xenoliths from Lesotho, and from the Westchester
Prong, PA, granulites. When the Davidson and Lindsley (1985) activities are reduced by an amount equal to the mole fraction of non-quadrilateral components $\left(1-\mathrm{Al}^{\mathrm{vi}}\right.$ $-2 \mathrm{Ti}-\mathrm{Fe}^{3+}-\mathrm{Mn}$ ), the degree of scatter is significantly reduced (Figs. $3 \mathrm{~d}, 3 \mathrm{e}$ ).

\section{Evaluation of barometers}

Pressures were calculated using the $\mathrm{Gt}-\mathrm{Cpx}-\mathrm{Pg}-\mathrm{Qz}$ (HD, DI) barometers (Reactions 1 and 2) and the $\mathrm{Gt}-\mathrm{Opx}-\mathrm{Pg}-\mathrm{Qz}$ (FS) geobarometer (Reaction 3) for 68 samples with $\mathrm{Gt}-\mathrm{Cpx}-\mathrm{Opx}-\mathrm{Pg}-\mathrm{Qz}$ assemblages (Tables 3 and 4). Widespread application of the FS barometer in the Central Gneiss Belt of the Grenville Province of Ontario has yielded pressures that are in good agreement with aluminosilicate occurrences and other geobarometers (Anovitz and Essene 1987b). The FS barometer also yields pressures that are consistent with reported aluminosilicate occurrences for the terranes studied here (Table 3) and previous estimates of pressure for other terranes (Table 4).

Shown in Fig. 4 are pressures obtained from the FS barometer as calculated for the different models for $a_{\mathrm{Fe}_{2} \mathrm{Si}_{2} \mathrm{O}_{6}}^{\mathrm{Opx}}$. 

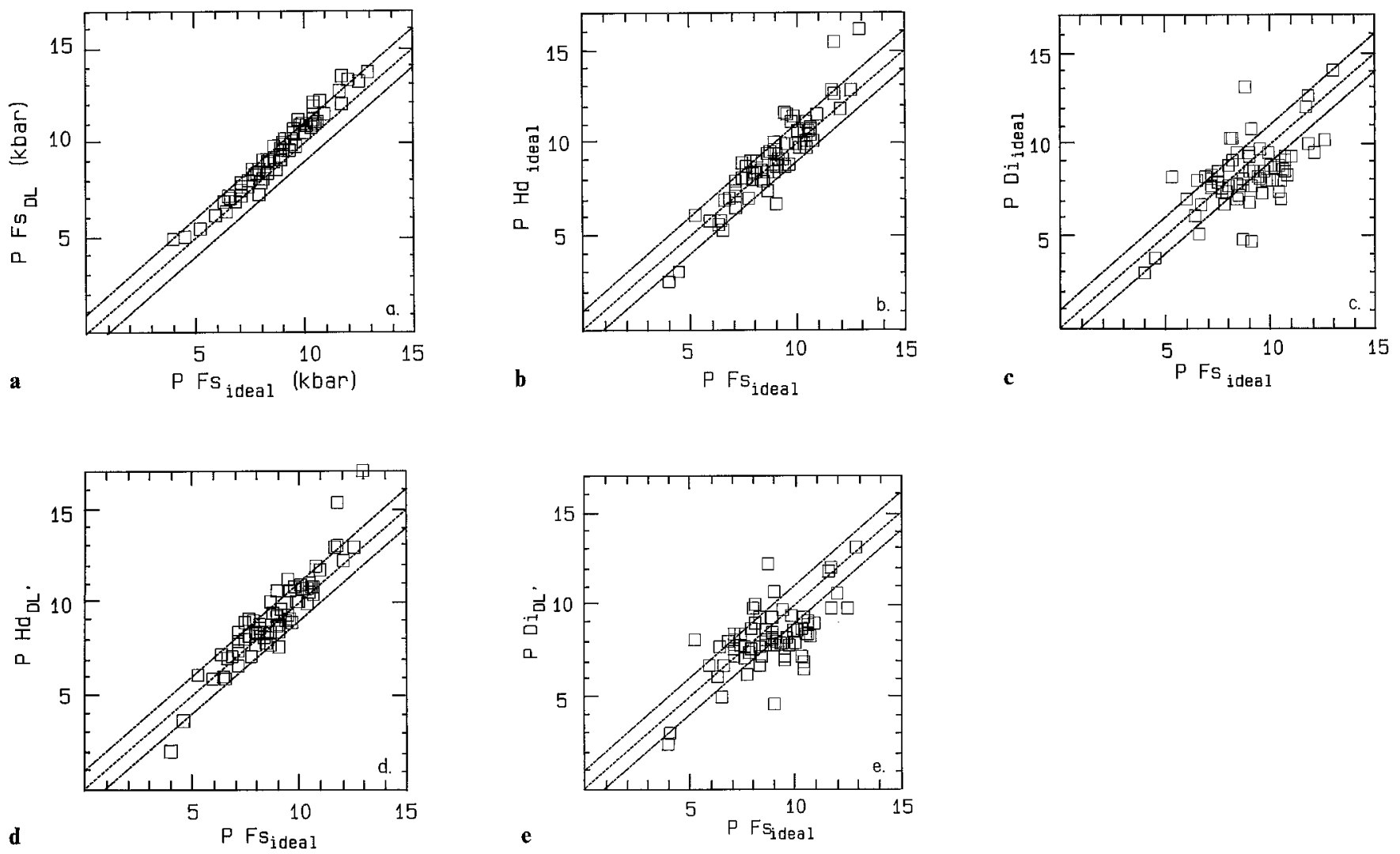

Fig. 4. a Pressures obtained for FS barometer with ideal activities for ferrosilite $\left(P_{\mathrm{Fs}}\right.$ ideal $)$ vs. pressure obtained with model of Davidson and Lindsley $\left(P_{\mathrm{Fs}} \mathrm{DL}\right)$; b Pressures obtained for HD barometer vs. those for FS barometer, both with ideal approximation for pyroxene activities; c Pressures obtained for DI barometer vs. those for FS barometer, both with ideal approximation for pyroxene activities; d Pressures obtained for HD barometer vs. those for FS barometer, with $a_{\mathrm{CaFeSi}}^{\mathrm{Cpx} \mathrm{O}_{6}}$ from DL adjusted for non-quadrilateral components $\left(D^{\prime}\right)$ and ideal model for ferrosilite; e Pressures obtained for DI barometer vs. those for FS barometer, with $a_{\mathrm{CaMgSi}}^{\mathrm{Cpx} \mathrm{O}_{6}}$ from DL adjusted for non-quadrilateral components ( $\mathrm{DL}^{\prime}$ ) and ideal model for ferrosilite

Using the Davidson and Lindsley (1985: DL) model one obtains slightly greater pressures than with the ideal model, with the greatest departures being at high pressures (low $a_{\mathrm{Fe}_{2} \mathrm{Si}_{2} \mathrm{O}_{6}}^{\mathrm{O}}$. The pressure difference between the two models is well within a liberal estimate of precision for the FS barometer of $\pm 1 \mathrm{kbar}$. If the DL ferrosilite activities are adjusted for non-quadrilateral components in a manner similar to clinopyroxene activities, the pressure difference does not change or increases on the order of only $0.1 \mathrm{kbar}$, because of the lower amount of non-quadrilateral components in Opx relative to Cpx. For convenience we will compare the HD and DI barometers using ideal ferrosilite activities for the FS barometer.

Pressures obtained for the HD and DI barometers are plotted against pressures obtained for the FS barometer in Figs. $4 \mathrm{~b}$ and $4 \mathrm{c}$, using ideal activities for clinopyroxene and orthopyroxene. There appears to be a significant difference between the two clinopyroxene barometers relative to the orthopyroxene barometer in terms of apparent relative pressure differences and apparent precision. Some 53 of the 68 pressures obtained for the HD barometer fall within $1 \mathrm{kbar}$ of equal pressure, with an average pressure difference $\left(P_{\mathrm{FS}}-P_{\mathrm{HD}}\right)$ of $-0.2 \pm 1.0(1 \sigma) \mathrm{kbar}$. For the DI barometer 28 of the 68 samples fall within $1 \mathrm{kbar}$ of the values obtained from the orthopyroxene barometer, and the average pressure difference $\left(P_{\mathrm{FS}}-P_{\mathrm{DI}}\right)$ is $0.6 \pm 1.6(1 \sigma) \mathrm{kbar}$. The same general distribution of pressures with slightly less scatter is observed if clinopyroxene component activities are calculated using the model of Davidson and Lindsley (1985), corrected for non-quadrilateral components (Figs. $4 \mathrm{~d}$ and $4 \mathrm{e})$.

We have also evaluated the HD and DI barometers by comparison with pressure constraints from reported aluminosilicate occurrences in high grade terranes (Table 4). For this purpose pyroxene activities were calculated using the ideal model. In general the HD barometer is consistent with aluminosilicate constraints when a reasonable temperature uncertainty is included, although pressures are overestimated for some samples from Parry Sound, Ontario, the Sargur Belt, India and the Furua Complex, Tanzania. The DI barometer yields pressures consistent with aluminosilicates, but pressures are lower than both the FS and HD barometers.

To a first approximation, the HD and DI barometers yield reasonable estimates of pressure for most garnet twopyroxene granulites, assuming the FS barometer is recording accurate pressures. Considering the possible sources of error in deriving the thermodynamic data, the agreement with FS pressures is satisfactory. The HD barometer shows a slight tendency to overestimate pressure relative to the FS barometer for some samples, and the DI barometer shows an opposite trend. In testing the barometers it was generally observed that the greatest pressure discrepancies using the HD barometer were for pyroxenes with a high 
Mg number $\left(100\left(\mathrm{Mg} /\left[\mathrm{Mg}+\mathrm{Fe}^{2+}\right]\right)\right.$, e.g., Doubtful Sound, $\mathrm{NZ}$, sample 36461. In general pyroxenes in the assemblage $\mathrm{Gt}-\mathrm{Cpx}-\mathrm{Opx}-\mathrm{Pg}-\mathrm{Qz}$ become more magnesian and aluminous with increasing pressure. Therefore higher pressures are accompanied by greater extrapolations from the end member Fe system and the pressures will be less reliable. Aside from the general tendency for the DI barometer to underestimate pressure, the DI barometer overestimates pressure in Fe-rich systems such as high grade banded iron formation from the Wind River Range and samples of $\mathrm{Fe}$ rich metabasites from the Adirondack Highlands and Minnesota River Valley. This accounts for the samples that fall 3 to $4 \mathrm{kbar}$ above the line of equal pressure in Figs. $4 \mathrm{c}$ and $4 \mathrm{e}$. Conversely, Mg-rich samples with Fe-poor Opx yield high FS pressures causing the largest excursions below the line of equal pressure (Fig. $4 \mathrm{c}, 4 \mathrm{e}$ ). The apparent disagreement between the DI and FS barometers is in part an artifact of the comparison scheme and is not seen when comparing the HD and FS barometers (Fig. 4b, 4d), because in Mg-rich rocks both $X_{\mathrm{CaFeSi}_{2} \mathrm{O}_{6}}^{\mathrm{Cpx}_{2}}$ and $X_{\mathrm{FeSSO}_{3}}^{\mathrm{O} \mathrm{ps}_{3}}$ will be low, yielding high pressures for both HD and FS. Therefore the highest pressures in Figs. $4 \mathrm{~b}$ and $4 \mathrm{~d}$ are likely to be overestimates of pressure. The data are consistent with a pressure dependence for extreme compositions, and in application of these barometers one should be aware of the possible errors involved in extrapolation of the HD barometer to $\mathrm{Mg}$-rich systems, and extrapolation of the DI barometer to Fe-rich systems.

The observed pressure difference for the DI barometer relative to the FS barometer cannot be a result of the clinopyroxene barometers equilibrating at lower pressure relative to the FS barometer. If the agreement in pressure between the HD and FS barometers is real, it suggests that the DI barometer is yielding lower pressures as a result of errors in thermodynamic data and/or activity models. The difference $\left(P_{\mathrm{FS}}-P_{\mathrm{DI}}\right)$ is well within a reasonable error in $\Delta G_{298}^{\circ}$ for any of the phases involved in the reaction, and we cannot identify any one phase as having an erroneous $\Delta G_{298}^{\circ}$. We believe the pressure discrepancy can be tied to ideal diopside activities. By assigning all the $\mathrm{Mg}$ to the $\mathrm{M} 1$ site, the ideal model for diopside (Eq. 18) may overestimate the activity of diopside, as some of the $\mathrm{Mg}$ is likely to partition into the M2 site (Cameron and Papike 1980; Dal Negro et al. 1983). This will tend to lower the $X_{\mathrm{Mg}}^{\mathrm{M} 1}$, decreasing the $a_{\mathrm{CaMgSi}}^{\mathrm{Cpx}} \mathrm{O}_{6}$ and raising the pressure calculated from Reaction 2. For example, diopside activities calculated using the Wood and Banno (1973) approximation (in which $\mathrm{Mg}$ and $\mathrm{Fe}^{2+}$ are equipartitioned between the $\mathrm{M} 1$ and $\mathrm{M} 2$ sites) raises pressures by 0.1 to $0.6 \mathrm{kbars}$, with the greatest pressure increase being for the most $\mathrm{Mg}$-rich clinopyroxenes.

The temperature dependence of the HD and DI barometers has been evaluated by carrying through a $\pm 50^{\circ} \mathrm{C}$ temperature uncertainty in the calculation of $\log _{10} \mathrm{~K}$ and pressure. For this temperature range the value of $\log _{10} K$ changes by only 1 to $2 \%$, but pressure varies by \pm 1.0 and $\pm 0.3 \mathrm{kbar}$ for the HD and DI barometers respectively. The former is a relatively high temperature dependence for a barometer and illustrates the need for reasonably precise temperatures $\left( \pm 30^{\circ} \mathrm{C}\right)$ when applying the $\mathrm{HD}$ barometer. Compositional variations on the order of $1 \mathrm{~mol} \%$ anorthite in plagioclase, hedenbergite and diopside in clinopyroxene, and almandine and pyrope in garnet correspond to pressure variations on the order of $0.1 \mathrm{kbar}$. A compositional variation of $1 \mathrm{~mol} \%$ grossular has approximately twice the effect as other components, as grossular activities are raised to a higher exponent in the expression for $\log _{10} K$.

\section{Application of barometers}

Orthopyroxene barometry is the preferred technique for calculating pressure in $\mathrm{Gt}-\mathrm{Opx}-\mathrm{Cpx}-\mathrm{Pg}-\mathrm{Qz}$ granulites. The available FS geobarometers have a sound experimental and thermodynamic basis, and modeling of $a-X$ relations for orthopyroxene is relatively straightforward. However, clinopyroxene barometry is required for rocks containing $\mathrm{Gt}-\mathrm{Cpx}-\mathrm{Pg}-\mathrm{Qz}$ assemblages without orthopyroxene. To evaluate the utility of the clinopyroxene barometers we have applied them to $\mathrm{Gt}-\mathrm{Cpx}-\mathrm{Pg}-\mathrm{Qz}$ assemblages in rocks from several high grade metamorphic terranes.

The Whitestone Anorthosite (WSA) is a $170 \mathrm{~km}^{2}$ gabbroic anorthosite body metamorphosed to granulite facies in the western Grenville Province of Ontario (Thompson 1983). $\mathrm{Gt}-\mathrm{Cpx}-\mathrm{Pg}-\mathrm{Qz}$ assemblages occur within the main body of the anorthosite and within segments of the WSA intersected by the Parry Sound Shear Zone (PSSZ), a high grade ductile shear zone separating a predominantly amphibolite facies tectonic domain from one at granulite facies (Davidson 1984, 1986). Calculation of pressure (using ideal activities) for samples within the main body of the WSA (Moecher 1988) average 9.8 (HD) and 9.5 (DI) kbar (at $750^{\circ} \mathrm{C}, \mathrm{Gt}-\mathrm{Cpx}$ thermometry), identical to regional metamorphic pressures deduced from a variety of geobarometers (10 $\pm 1.0 \mathrm{kbar}$, Anovitz and Essene $1987 \mathrm{~b})$. In comparison, pressures from assemblages within the PSSZ average $10.8(\mathrm{HD})$ and $11.4 \mathrm{kbar}(\mathrm{DI})$ at $700^{\circ} \mathrm{C}(\mathrm{Gt}-\mathrm{Cpx}$ thermometry), or essentially the same as the regional data considering a $1 \mathrm{kbar}$ pressure uncertainty. The pressures are consistent with the occurrence of kyanite in pelitic gneisses within the PSSZ $\left(P>7.8 \pm 1.0 \mathrm{kbar}\right.$ at $\left.700 \pm 50^{\circ} \mathrm{C}\right)$, and in dicate that ductile shearing occurred in a deep crustal setting.

$\mathrm{Gt}-\mathrm{Cpx}-\mathrm{Pg}-\mathrm{Qz}-( \pm \mathrm{Wo} \pm \mathrm{Cc} \pm$ Scap $)$ assemblages are also common in calc-silicate rocks from the western Grenville Province. The primary compositional difference between calc-silicate and mafic granulite assemblages is that garnet in the calc-silicates has higher $X_{\mathrm{Ca}}^{\mathrm{Gt}}$, and lower $X_{\mathrm{Fe}^{2}+}^{\mathrm{Gt}}$ and $X_{\mathrm{Mg}}^{\mathrm{Gt}}$ than in mafic rocks. Clinopyroxene is typically a diopside-hedenbergite solid solution with minor $\mathrm{Al}, \mathrm{Fe}^{3+}$ and $\mathrm{Na}$, and plagioclase shows the same range of composition as in samples of mafic granulite. Calc-silicate assemblages from the Parry Sound-Muskoka area of Ontario (Moecher, unpbl data) with high $X_{\mathrm{Ca}}^{\mathrm{Gt}}(>0.90)$ yield unrealistic pressures (13 to $15 \mathrm{kbar}$ ) using the HD barometer and low pressures using the DI barometer (5-6 kbar), with pressure varying widely with slight variations in $X_{\mathrm{Fe}^{2}}^{\mathrm{Gt}}$, and $X_{\mathrm{Mg}}^{\mathrm{Gt}}$. It is likely that the garnet activity model used here is not accurate at such extreme garnet compositions, and in garnet with large amounts of andradite component. However, some calc-silicate samples with intermediate garnet compositions (e.g., $X_{\mathrm{Ca}}^{\mathrm{Gt}}=0.35$ to $0.40, X_{\mathrm{Fe}^{2+}}^{\mathrm{Gt}}=0.45$ to 0.55 ) yield pressures (8.9 (DI) to $11.9 \mathrm{kbar}(\mathrm{HD}))$ that are consistent with regional pressure estimates (Anovitz and Essene 1987b). To avoid the subjective choice of which samples yield accurate pressure, calculations based on Reaction 10 would be more appropriate for high grade calc-silicate rocks.

Percival (1983) describes $\mathrm{Gt}-\mathrm{Cpx}-\mathrm{Pg}-\mathrm{Qz}-( \pm \mathrm{Hbl}$ $\pm \mathrm{Ilm} \pm \mathrm{Ti}$ ) assemblages in mafic gneisses from the Chap- 
leau-Foleyet area of the Wawa Belt of western Ontario, which are regarded as a cross section of deep crust upthrust along the Kapuskasing Structural Zone (Percival and McGrath 1986). Sillimanite is the only aluminosilicate found and is reported in one sample from this terrane. Application of the DI barometer of Newton and Perkins (1982) yields pressures in the range 3.9 to $8.3 \mathrm{kbar}$, with an average of $6.3 \mathrm{kbar}$ for peak temperatures of $800^{\circ} \mathrm{C}$ (Percival 1983). These values do not include the $+1.6 \mathrm{kbar}$ correction suggested by Newton and Perkins (1982) which would raise the average pressure to approximately $7.9 \mathrm{kbar}$. $\mathrm{Gt}-\mathrm{Opx}-\mathrm{Pg}-\mathrm{Qz}$ barometry by Percival and McGrath (1986) yield pressures that average $9.4 \mathrm{kbar}$ (at $800^{\circ} \mathrm{C}$ ) using the FS barometers of Bohlen et al. (1983a) and Perkins and Chipera (1985). The FS barometry indicates that the DI barometer of Newton and Perkins (1982) underestimates pressure by $3.1 \mathrm{kbar}$ for these samples. We have applied the present clinopyroxene barometers to 27 samples of $\mathrm{Gt}-\mathrm{Cpx}-\mathrm{Pg}-\mathrm{Qz}$ metabasites from this terrane, obtaining pressures from the $\mathrm{HD}$ and DI barometers that average $9.6 \pm 1.3 \mathrm{kbars}(\mathrm{HD}, 1 \sigma)$ and $8.9 \pm 1.4 \mathrm{kbar}(\mathrm{DI})$. Some of the pressure variation may be real variations in regional pressure. The pressures are consistent with a maximum pressure of approximately $10 \mathrm{kbar}$ imposed by the occurrence of sillimanite at $800^{\circ} \mathrm{C}$, and are in excellent agreement with the orthopyroxene barometry.

Tella and Eade (1986) report Gt $-\mathrm{Cpx}-\mathrm{Pg}-\mathrm{Qz}$ assemblages in fragments of mafic gneisses entrained within the Tulemalu fault zone, a high grade ductile shear zone in the Northwest Territories, Canada. The samples are interpreted as deep crustal relicts brought to the surface in granitic melts along the shear zone during ductile displacements. At temperatures of $750 \pm 50^{\circ} \mathrm{C}$, the DI barometer of Newton and Perkins (1982) yielded pressures that average $10.9 \mathrm{kbar}$ (unadjusted for the $1.6 \mathrm{kbar}$ pressure correction). The clinopyroxene barometers of this study yield 12.9 (HD) and 11.7 (DI) kbar. It is difficult to evaluate the accuracy of these values without other petrologic constraints on pressure.

Ghent et al. (1983) have mapped a prograde Gt-Cpx isograd in sillimanite zone metabasites $(\mathrm{Hbl}-\mathrm{Pg}-\mathrm{Ilm}$ $\pm \mathrm{Qz} \pm \mathrm{Gt} \pm \mathrm{Cpx} \pm \mathrm{Cc} \pm \mathrm{Ti}$ ) from Mica Creek, British Columbia. The $\mathrm{Gt}-\mathrm{Cpx}$ isograd nearly coincides with a kyanite-sillimanite isograd, placing excellent constraints on maximum pressure of $7.8 \pm 1 \mathrm{kbar}$ at an upper temperature limit of $700^{\circ} \mathrm{C}$ (based on Gt $-\mathrm{Cpx}$ thermometry). The DI barometer of Newton and Perkins (with correction) yields pressures of $7.2 \pm 0.3 \mathrm{kbar}$ at $650^{\circ} \mathrm{C}$ (Ghent et al. 1983, 8 samples). In lower grade rocks containing kyanite, Ghent et al. (1979) and Newton and Haselton (1981) quote pressures of 6.6 to $8.9 \mathrm{kbar}$ at approximately $575 \pm 50^{\circ} \mathrm{C}$ using the reaction

Anorthite $=$ Grossular + Kyanite + Quartz

$3 \mathrm{CaAl}_{2} \mathrm{Si}_{2} \mathrm{O}_{8}=\mathrm{Ca}_{3} \mathrm{Al}_{2} \mathrm{Si}_{3} \mathrm{O}_{12}+2 \mathrm{Al}_{2} \mathrm{SiO}_{5}+\mathrm{SiO}_{2}$

(Ghent 1976). The clinopyroxene barometers of the present study yield apparently high values of $9.8 \pm 0.9$ (HD) and $10.5 \pm 0.6(\mathrm{DI}) \mathrm{kbar}$ at $650^{\circ} \mathrm{C}$. The reason for this discrepancy is not immediately apparent. Ghent et al. (1983) see no structural evidence for an increase in pressure for the higher grade rocks near the sillimanite isograd, relative to lower grade rocks below the sillimanite isograd and that yield pressures approaching those calculated for the mafic gneis- ses. It appears for these rocks that the clinopyroxene barometers overestimate pressure by about $2-3 \mathrm{kbar}$, although the upper limit of pressure obtained from Reaction 18 overlaps the lower limit of pressure for the clinopyroxene barometers assuming an error estimate of about 1 kbar.

Sanders et al. (1987) describe high pressure granulite facies gneisses from the Northeast $\mathrm{Ox}$ Inlier of northwestern Ireland. $\mathrm{Gt}-\mathrm{Cpx}-\mathrm{Pg}-\mathrm{Qz}-\mathrm{Ilm}-\mathrm{Ru}$ metabasites interpreted as decompressed eclogites occur with metapelites, metapsammites, and ultramafites. Sieve-texture intergrowths of clinopyroxene and plagioclase are interpreted to be a result of exsolution of an original omphacitic clinopyroxene. As with the Doubtful Sound, NZ samples, the presently preserved clinopyroxenes are magnesian $\left(X_{\mathrm{HD}}^{\mathrm{Cpx}}\right.$ $=0.03$ to 0.10 ) and relatively high in $\mathrm{Al}_{2} \mathrm{O}_{3}$ (up to $8 \mathrm{wt} \%$ $\mathrm{Al}_{2} \mathrm{O}_{3}$ ). Peak temperatures are estimated at $850-900^{\circ} \mathrm{C}$, based on $\mathrm{Gt}-\mathrm{Cpx}$ thermometry and the presence of mesoperthite, and the occurrence of kyanite in pelites (Gt $-\mathrm{Ky}-\mathrm{Pg}-\mathrm{Kfs}-\mathrm{Qz}-\mathrm{Ru}$ ) places a minimum constraint on pressure of 10.8 to $11.8 \mathrm{kbar}$ at $850-900^{\circ} \mathrm{C}$. Pressure estimates for the metabasites from $\mathrm{Gt}-\mathrm{Cpx}$ core compositions range from 19 (HD) to 15 (DI) kbar, and 16 (HD) to 13 (DI) kbar for rim compositions. In view of the tendency of $\mathrm{HD}$ barometer to overestimate pressure for $\mathrm{Mg}$ rich clinopyroxenes, the HD values are likely to be upper limits on pressure. However pressures calculated from Reaction 18 for the $\mathrm{Gt}-\mathrm{Ky}-\mathrm{Pg}-\mathrm{Qz}$ assemblage reported by Sanders et al. (1987), using the calibration of Newton and Haselton (1981) and Essene (unpl. data), are also in excess of $15 \mathrm{kbars}$ (at $800^{\circ} \mathrm{C}$ ), in agreement with the DI barometer. Pressures calculated from $\mathrm{Gt}-\mathrm{Pg}-\mathrm{Ilm}-\mathrm{Ru}-\mathrm{Qz}$ assemblages in the metabasite (Reaction 8: Anovitz and Essene $1987 \mathrm{a}$ yield minimum pressure estimates of 12 to $13 \mathrm{kbar}$ (assuming $a_{\mathrm{FeTiO}_{3}}^{\mathrm{Ilm}}=1$ ). If equilibrium can be demonstrated for the sieve-texture clinopyroxenes then the pressures indicated by the geobarometry are consistent as a whole with the extremely deep crustal history for these samples suggested by Sanders et al. (1987).

Wood (1975) presents analyses for coexisting garnet, clinopyroxene inclusions within garnet, and plagioclase from metagabbros from the South Harris, Scotland, Igneous Complex. The presence of kyanite in metapelites associated with the meta-igneous lithologies places a lower limit on pressure of $9 \mathrm{kbar}$. Pressures were estimated to range from 10 to $13 \mathrm{kbar}$ at 800 to $860^{\circ} \mathrm{C}$ (two-pyroxene and $\mathrm{Gt}-\mathrm{Cpx}$ thermometry), based on constraints from $\mathrm{Gt}-\mathrm{Ol}-\mathrm{Pg}$ and $\mathrm{Gt}-\mathrm{Opx}-\mathrm{Pg}-\mathrm{Qz}$ barometry. We have recalculated the $\mathrm{Gt}-\mathrm{Cpx}$ temperatures to be $750^{\circ} \mathrm{C}$ using the Ellis and Green (1979) thermometer, and these are likely to be lower limits on temperature as garnet and clinopyroxene in contact with one another tend to re-equilibrate with falling temperature after the peak of metamorphism (Johnson et al. 1983; Moecher et al. 1986). Pressures for three samples average $12.3(\mathrm{HD})$ and $10.6(\mathrm{DI}) \mathrm{kbar}$. One sample with $X_{\mathrm{Hd}}^{\mathrm{Cpx}}$ $=0.07$ yields the highest pressure, and as with the samples from Doubtful Sound, NZ and the Northeast Ox Inlier, Ireland, this is likely to yield an overestimate of pressure. Excluding this sample the average HD pressure is $11.3 \mathrm{kbar}$. Metamorphic pressure for the South Harris area is likely to be $11 \pm 1 \mathrm{kbar}$, essentially that predicted by Wood's earlier analysis.

Evaluation of the HD and DI barometers in previous sections indicated that the DI barometer tended to yield somewhat lower and more scattered pressures than the HD 
and FS barometers. The results from the six areas above indicate that the two clinopyroxene barometers are in better agreement with one another. This is not inconsistent with the former observation, as some of the garnet two-pyroxene granulites yield similar pressures for all three barometers. From the foregoing applications it is apparent that the clinopyroxene barometers of this study can yield reasonable pressures for most $\mathrm{Gt}-\mathrm{Cpx}-\mathrm{Pg}-\mathrm{Qz}$ assemblages. In the absence of assemblages for which experimentally determined geobarometers are available, the HD and DI barometers can be applied with reasonable precision in the granulite facies. However, the thermodynamic, temperature, and compositional dependencies of these barometers, and the inherently less precise nature of calibrations based largely on thermodynamic data compared to reversed experiments, must be kept in mind when applying the barometers in natural settings. More accurate calibrations of these barometers will require careful experiments on Reactions 1 and 2 , or on the reactions that constrain the $\Delta G_{298}^{\circ}$ of hedenbergite and pyrope.

Acknowledgments. This work was supported in part by NSF grant EAR 84-08169 to EJE, and Grants in Aid from GSA, Sigma Xi, and the Turner Fund of the University of Michigan to DPM and LMA. We greatly appreciate the critical comments of H.T. Haselton and an anonymous reviewer. Paula Davidson kindly provided a PC version of her quadrilateral pyroxene activity program. Z.D. Sharp and M.A. Cosca provided valuable technical assistance. The electron microprobe analyzer used in this study was obtained under the auspices of NSF grant EAR 82-12764.

\section{References}

Anastasiou P, Seifert F (1972) Solid solubility of $\mathrm{Al}_{2} \mathrm{O}_{3}$ in enstatite at high temperature and $1-5 \mathrm{kbar}$ water pressure. Contrib Mineral Petrol 34:272-287

Anovitz LM, Essene EJ (1987a) Compatibility of geobarometers in the system $\mathrm{CaO}-\mathrm{FeO}-\mathrm{Al}_{2} \mathrm{O}_{3}-\mathrm{SiO}_{2}-\mathrm{TiO}_{2}$ : implications for garnet mixing models. J Geol 95:633-645

Anovitz LM, Essene EJ (1987 b) Thermobarometry in the Grenville Province of Ontario. $J$ Petrol, in press

Aranovich LYa, Kosyakova NA (1987) The cordierite=orthopyroxene + quartz equilibrium: laboratory data on and thermodynamics of ternary $\mathrm{Fe}-\mathrm{Mg}-\mathrm{Al}$ orthopyroxene solid solutions. Geochem Int 24:111-131

Babuska V, Fiala J, Kumazawa M, Ohno I (1978) Elastic properties of garnet solid-solution series. Phys Earth Plan Int 16:157-176

Bass JD, Weidner DJ (1984) Elasticity of single-crystal orthoferrosilite. J Geophys Res 89:4359-4372

Bennington KO, Beyer RP, Brown RR (1984) Thermodynamic properties of hedenbergite, a complex silicate of $\mathrm{Ca}, \mathrm{Fe}, \mathrm{Mn}$ and Mg. US Dept Int Rept Inv 8873:19 p

Berman RG, Brown TH (1985) Heat capacity of minerals in the system $\quad \mathrm{Na}_{2} \mathrm{O}-\mathrm{K}_{2} \mathrm{O}-\mathrm{CaO}-\mathrm{MgO}-\mathrm{FeO}-\mathrm{Fe}_{2} \mathrm{O}_{3}-\mathrm{Al}_{2} \mathrm{O}_{3}$ $-\mathrm{SiO}_{2}-\mathrm{TiO}_{2}-\mathrm{H}_{2} \mathrm{O}-\mathrm{CO}_{2}$ : representation, estimation, and high temperature extrapolation. Contrib Mineral Petrol $89: 168-183$

Berman RG, Engi M, Greenwood HJ, Brown TH (1986) Derivation of internally consistent thermodynamic data by the technique of mathematical programming: a review with application to the system $\mathrm{MgO}-\mathrm{SiO}_{2}-\mathrm{H}_{2} \mathrm{O}$. J Petrol 27:1331-1364

Bhattacharyya PK, Mukherjee S (1987) Granulites in and around the Bengal anorthosite, eastern India; genesis of coronal garnet, and evolution of the granulite-anorthosite complex. Geol Mag $124: 21-32$

Birch F (1966) Compressibility: elastic constants. In: Clark SP Jr (ed) Handbook of Physical Constants. Geol Soc Am Mem 97:97-173
Boettcher $\mathrm{AL}(1970)$ The system $\mathrm{CaO}-\mathrm{Al}_{2} \mathrm{O}_{3}-\mathrm{SiO}_{2}-\mathrm{H}_{2} \mathrm{O}$ at high pressure and temperature. J Petrol 11:337-379

Bohlen SR (1979) Pressure, Temperature, and Fluid Composition of Adirondack Metamorphism as Determined in Orthogneisses, Adirondack Mountains, New York. PhD Thesis Univ Michigan

Bohlen SR, Boettcher AL (1982) Experimental investigations and geological applications of orthopyroxene geobarometry. Am Mineral 66:951-964

Bohlen SR, Essene EJ, Boettcher AL (1980) Reinvestigation and application of olivine-quartz-orthopyroxene barometry. Earth Planet Sci Lett 47:1-10

Bohlen SR, Liotta JJ (1986) A new barometer for garnet amphibolites and garnet granulites. J Petrol 27:1025-1034

Bohlen SR, Metz GW, Essene EJ, Anovitz LM, Westrum EF Jr, Wall VJ (1983) Thermodynamics and phase equilibria of ferrosilite: potential oxygen barometer in mantle rocks. Eos 64:350

Bohlen SR, Wall VJ, Boettcher AL (1983a) Experimental investigation of model garnet granulite equilibria. Contrib Mineral Petrol 83:52-61

Bohlen SR, Wall VJ, Boettcher AL (1983 b) Experimental investigations and applications of equilibria in the system $\mathrm{FeO}-\mathrm{TiO}_{2}$ $-\mathrm{Al}_{2} \mathrm{O}_{3}-\mathrm{SiO}_{2}-\mathrm{H}_{2} \mathrm{O}$. Am Mineral 68:1049-1058

Bohlen SR, Wall VJ, Boettcher AL (1983c) Geobarometry in granulites. In: Saxena SK (ed) Kinetics and Equilibrium in Mineral Reactions. Springer, Berlin Heidelberg New York Tokyo, pp 141-171

Boyd FR, England JL (1964) The system enstatite-pyrope. Carnegie Inst Wash Yrbk 63:157-161

Brace WF, Scholz CH, La Mori PN (1969) Isothermal compressibility of kyanite, andalusite, and sillimanite from synthetic aggregates. J Geophys Res 74:2089-2098

Burton JC, Taylor LA, Chou I-M (1982) The $f \mathrm{O}_{2}-\mathrm{T}$ and $f \mathrm{~S}_{2}-\mathrm{T}$ stability relations of hedenbergite and of hedenbergite-johannsenite solid solutions. Econ Geol 77:764-783

Cameron M, Sueno S, Prewitt CT, Papike JJ (1973) High temperature crystal chemistry of acmite, diopside, hedenbergite, jadeite, spodumene, and ureyite. Am Mineral 58:594 618

Cameron M, Papike JJ (1980) Crystal chemistry of silicate pyroxenes. In: Prewitt CT (ed) Reviews in Mineralogy 7, Pyroxenes. Mineralogical Society of America, Washington DC, pp 5-92

Chatillon-Colinet C, Newton RC, Perkins D III, Kleppa OJ (1983) Thermochemistry of $\left(\mathrm{Fe}^{2+}, \mathrm{Mg}\right) \mathrm{SiO}_{3}$ orthopyroxene. Geochim Cosmochim Acta 47:1597-1603

Coolen JJMMM (1980) Chemical petrology of the Furua Granulite Complex, southern Tanzania. PhD Thesis Vrije Univ

Dal Negro A, Carbonin S, Molin GM, Cundari A, Piccirillo EM (1982) Intracrystalline cation distribution in natural clinopyroxenes of tholeiitic, transitional, and alkaline basaltic rocks. In: Saxena SK (ed) Advances in Physical Geochemistry, Vol 2, Springer, Berlin Heidelberg New York, pp 117-150

Danckwerth PA, Newton RC (1978) Experimental determination of the spinel peridotite to garnet peridotite reactions in the system $\mathrm{MgO}-\mathrm{Al}_{2} \mathrm{O}_{3}-\mathrm{SiO}_{2}$ in the range $900-1100^{\circ} \mathrm{C}$ and $\mathrm{Al}_{2} \mathrm{O}_{3}$ isopleths of enstatite in the spinel field. Contrib Mineral Petrol 66:189-201

Davidson A (1984) Tectonic boundaries within the Grenville Province of the Canadian Shield. J Geodynam 1:433-444

Davidson A (1986) New interpretations in the southwestern Grenville Province. In: Moore JM, Davidson A, Baer AJ (eds) The Grenville Province. Geol Assoc Can Spec Pap 31:61-74

Davidson PM, Lindsley DH (1985) Thermodynamic analysis of quadrilateral pyroxenes Part II: model calibration from experiments and application to geothermometry. Contrib Mineral Petrol 91:390-404

Devaraju TC, Coolen JJMMM (1983) Mineral chemistry and P-T conditions of formation of a basic scapolite-garnet-pyroxene granulite from Doddakanya, Mysore District. J Geol Soc India 24:404-411

Ellis DJ, Green DH (1979) An experimental study of the effect of $\mathrm{Ca}$ upon garnet-clinopyroxene $\mathrm{Fe}-\mathrm{Mg}$ exchange equilibria. Contrib Mineral Petrol 71:13-22 
Ganguly J, Saxena SK (1984) Mixing properties of aluminosilicate garnets: constraints from natural and experimental data, and applications to geothermobarometry. Am Mineral 68:88-97

Gasparik T (1984a) Experimental study of subsolidus phase relations and mixing properties in the system $\mathrm{CaO}-\mathrm{Al}_{2} \mathrm{O}_{3}-\mathrm{SiO}_{2}$. Geochim. Cosmochim. Acta 48:2537-2546

Gasparik T (1984b) Experimentally determined stability of clinopyroxene + garnet + corundum in the system $\mathrm{CaO}-\mathrm{MgO}$ $-\mathrm{Al}_{2} \mathrm{O}_{3}-\mathrm{SiO}_{2}$. Am Mineral 69:1025-1035

Gasparik T, Newton RC (1984) The reversed alumina contents of orthopyroxene in equilibrium with spinel and forsterite in the system $\mathrm{MgO}-\mathrm{Al}_{2} \mathrm{O}_{3}-\mathrm{SiO}_{2}$. Contrib Mineral Petrol $85: 186-196$

Ghent ED (1976) Plagioclase-garnet- $\mathrm{Al}_{2} \mathrm{SiO}_{5}$-quartz: a potential geobarometer - geothermometer. Am Mineral 61:710-714

Ghent ED, Robbins DB, Stout MZ (1979) Geothermometry, geobarometry, and fluid compositions of metamorphosed calcsilicates and pelites, Mica Creek, British Columbia. Am Mineral 64:874-885

Ghent ED, Stout MV, Raeside RP (1983) Plagioclase-clinopyroxene-garnet-quartz equilibria and the geobarometry and geothermometry of garnet amphibolites from Mica Creek, British Columbia. Can J Earth Sci 20:699-706

Glassley WE, Sorensen K (1980) Constant $P_{s}-T$ amphibolite to granulite facies transition in Agto (West Greenland) metadolerites: implications and applications. J Petrol 21:69-105

Griffin WL, Carswell DA, Nixon PH (1979) Lower-crustal granulites and eclogites from Lesotho, Southern Africa. In: Boyd FR, Meyer HOA (eds) The Mantle Sample: Inclusions in Kimberlites and Other Volcanics. American Geophysical Union, Wash DC, pp 59-86

Gustafson WI (1974) The stability of andradite, hedenbergite, and related minerals in the system $\mathrm{Ca}-\mathrm{Fe}-\mathrm{Si}-\mathrm{O}-\mathrm{H}$. J Petrol $15: 455-496$

Hansen EC, Newton RC, Janardhan AS (1984) Pressures, temperatures and metamorphic fluids across an unbroken amphibolite facies to granulite facies transition in southern Karnataka, India. In: Kroner A, Hanson GN, Goodwin AM (eds) Archaean Geochemistry, Springer, Berlin Heidelberg New York Tokyo, pp 161-181

Harris NBW, Holt RW, Drury SA (1982) Geobarometry, geothermometry, and late Archean geotherms from the granulite facies terrain of south India. J Geol 90:509-527

Haselton HT, Newton RC (1980) Thermodynamics of pyrope-grossular garnets and their stabilities at high temperatures and high pressure. J Geophys Res 85 B:6973-6982

Haselton HT, Westrum EF Jr (1980) Low temperature heat capacities of synthetic pyrope, grossular, and pyrope ${ }_{60}$ grossular $_{40}$. Geochim Cosmochim Acta 44:701-709

Haselton HT, Robie RA, Hemingway BS (1987) Heat capacities of synthetic hedenbergite, ferrobustamite and $\mathrm{CaFeSi}_{2} \mathrm{O}_{6}$ glass. Geochim Cosmochim Acta 51:2211-2218

Hays JF (1967) Lime-alumina-silica. Carnegie Inst Wash Yrbk 65:234-239

Hazen RM, Finger LW (1978) Crystal structures and compressibilities of pyrope and grossular to $60 \mathrm{kbar}$. Am Mineral 63:297303

Hazen RM, Finger LW (1981) Crystal structure of diopside at high temperature and pressure. Carnegie Inst Wash $\mathrm{Yb} 80: 373$ 376

Hazen RM, Prewitt CT (1977) Effects of temperature and pressure on interatomic distances in oxygen-based minerals. Am Mineral 62:309-315

Helgeson HC, Delany JM, Nesbitt HW, Bird DK (1978) Summary and critique of the thermodynamic properties of rock-forming minerals. Am J Sci 278-A:229 p

Hemingway BS (1987) Quartz: heat capacities from 340 to $1000 \mathrm{~K}$ and revised values for the thermodynamic properties. Am Mineral 72:273-279

Hensen BJ, Essene EJ (1971) Stability of pyrope-quartz in the system $\mathrm{MgO}-\mathrm{Al}_{2} \mathrm{O}_{3}-\mathrm{SiO}_{2}$. Contrib Mineral Petrol 30:72-83
Holdaway MJ (1971) Stability of andalusite and the aluminum silicate phase diagram. Am J Sci 271:97-131

Holmes RD, O'Neill HSt-C, Arculus RJ (1986) Standard Gibbs free energy of formation for $\mathrm{Cu}_{2} \mathrm{O}, \mathrm{NiO}, \mathrm{CoO}$, and $\mathrm{Fe}_{\mathrm{x}} \mathrm{O}$ : high resolution electrochemical measurements using zirconia solid electrolytes from 900-1400 K. Geochim Cosmochim Acta 50:2439-2452

Hörmann PK, Raith M, Raase P, Ackermand D, Seifert F (1980) The granulite complex of Finnish Lapland: petrology and metamorphic conditions in the Ivalojoki-Inarijarvi area. Bull Geol Surv Finland 308:95 pp

Huckenholz HG, Hölz E, Lindhuber W (1975) Grossularite, its solidus and liquidus relations in the $\mathrm{CaO}-\mathrm{Al}_{2} \mathrm{O}_{3}-\mathrm{SiO}_{2}-\mathrm{H}_{2} \mathrm{O}$ system up to 10 kbar. Neues Jahrb Mineral Abh 124:1-46

Huckenholz HG, Lindhuber W, Springer J (1974) The join $\mathrm{CaSiO}_{3}-\mathrm{Al}_{2} \mathrm{O}_{3}-\mathrm{Fe}_{2} \mathrm{O}_{3}$ of the $\mathrm{CaO}-\mathrm{Al}_{2} \mathrm{O}_{3}-\mathrm{Fe}_{2} \mathrm{O}_{3}-\mathrm{SiO}_{2}$ system and its bearing on the formation of granditic garnets and fassaitic pyroxenes. Neues Jahr Mineral Abh 121:160-207

Janardhan AS, Gopalkrishna D (1983) Pressure-temperature estimates of the basic granulites and conditions of metamorphism in Sargur Terrain, southern Karnataka and adjoining areas. $\mathrm{J}$ Geol Soc India 24:219-228

Janardhan AS, Newton RC, Hansen EC (1982) The transformation of amphibolite facies gneisses to charnockite in southern Karnataka and northern Tamil Nadu, India. Contrib Mineral Petrol 79:130-149

Johnson CA, Bohlen SR, Essene EJ (1983) An evaluation of garnetclinopyroxene geothermometry in granulites. Contrib Mineral Petrol 84:191-198

Koziol AM, Newton RC (1988) Redermination of the anorthite breakdown reaction and improvement of the plagioclase-garnet- $\mathrm{Al}_{2} \mathrm{SiO}_{5}$-quartz geobarometer. Am Mineral 73:216-223

Krupka KM, Hemingway BS, Robie RA, Kerrick DM, Ito J (1985a) Low-temperature heat capacities and derived thermodynamic properties of anthophyllite, diopside, enstatite, bronzite, and wollastonite. Am Mineral 70:249-260

Krupka KM, Hemingway BS, Robie RA, Kerrick DM (1985b) High-temperature heat capacities and derived thermodynamic properties of anthophyllite, diopside, dolomite, enstatite, bronzite, talc, tremolite, and wollastonite. Am Mineral 70:262271

Lane DL, Ganguly J (1980) $\mathrm{Al}_{2} \mathrm{O}_{3}$ solubility of orthopyroxene in the system $\mathrm{MgO}-\mathrm{Al}_{2} \mathrm{O}_{3}$ : a reevaluation, and mantle geotherm. J Geophys Res 85B:6963-6972

Levien L, Prewitt CT (1981) High-pressure structural study of diopside. Am Mineral 66:315-323

Liebermann RC, Ringwood AE (1976) Elastic properties of anorthite and the nature of the lunar crust. Earth Planet Sci Lett $8: 361-374$

Lindsley DH (1983) Pyroxene thermometry. Am Mineral 68:477493

Liou JG (1974) Stability relations of andradite-quartz in the system $\mathrm{Ca}-\mathrm{Fe}-\mathrm{Si}-\mathrm{O}-\mathrm{H}$. Am Mineral 59:1016-1025

MacGregor ID (1974) The system $\mathrm{MgO}-\mathrm{Al}_{2} \mathrm{O}_{3}-\mathrm{SiO}_{2}$ : solubility of $\mathrm{Al}_{2} \mathrm{O}_{3}$ in enstatite for spinel and garnet peridotite compositions. Am Mineral 59:110-119

Metz GW, Anovitz LM, Essene EJ, Bohlen SR, Westrum EF Jr (1983) The heat capacity and phase equilibria of almandine. Eos 64:346-347

Moecher DP (1984) Determination of Late Archean Metamorphic Conditions, Granite Falls, Minnesota. S Thesis Univ Wisconsin

Moecher DP (1988) Application of scapolite phase equilibria and carbon isotope systematics to high grade rocks: a test of the $\mathrm{CO}_{2}$-flooding hypothesis. PhD Thesis Univ Michigan

Moecher DP, Perkins D III, Leier-Englehardt PJ, Medaris LG Jr (1986) Metamorphic conditions of late Archean high-grade gneisses. Minnesota River valley, USA. Can J Earth Sci 23:633 645

Mora Cl, Valley JW (1985) Ternary feldspar thermometry in granulites from the Oaxacan Complex. Mexico. Contrib Mineral Petrol 89:215-225 
Newton RC (1966) Some calc-silicate equilibrium relations. Am J Sci 264:204-222

Newton RC (1983) Geobarometry of high-grade metamorphic rocks. Am J Sci $283 \mathrm{~A}: 1-28$

Newton RC (1987) Thermodynamic analysis of phase equilibria in simple mineral systems. In: Carmichael ISE, Eugster HP (eds) Thermodynamic Modeling of Geological Materials: Minerals, Fluids, and Melts, Reviews in Mineralogy 17, Mineralogical Society of America, Washington, DC, pp 1-33

Newton RC, Charlu TV, Kleppa OJ (1980) Thermochemistry of the high structure state plagioclases. Geochim Cosmochim Acta 44:933-941

Newton RC, Haselton HT (1981) Thermodynamics of the garnetplagioclase- $\mathrm{Al}_{2} \mathrm{SiO}_{5}$-quartz geobarometer. In: Newton RC, Navrotsky A, Wood BJ (eds) Thermodynamics of Minerals and Melts, Springer, Berlin Heidelberg New York, pp 129-145

Newton RC, Perkins D III (1982) Thermodynamic calibrations of geobarometers for charnockites and basic granulites based on the assemblages garnet-plagioclase-orthopyroxene-(clinopyroxene)-quartz, with applications to high grade metamorphism. Am Mineral 67:203-222

Nielson TH, Leipold MH (1965) Thermal expansion of NiO. J Am Ceramic Soc 48:164

Oliver GJH (1977) Feldspathic hornblende and garnet granulites and associated anorthosite pegmatites from Doubtful Sound, Fiordland, New Zealand. Contrib Mineral Petrol 65:111121

Orville PM (1972) Plagioclase cation exchange equilibria with aqueous chloride solution: results at $700^{\circ} \mathrm{C}$ and 2000 bars in the presence of quartz. Am J Sci 272:234-272

Paktunc AD, Baer AJ (1986) Geothermobarometry of the northwest margin of the Superior Province: implications for its tectonic evolution. J Geol 94:381-394

Percival JA (1983) High-grade metamorphism in the ChapleauFoleyet area, Ontario. Am Mineral 68:667-686

Percival JA, McGrath PH (1986) Crustal structure of the northern Kapuskasing uplift of Ontario: an integrated petrological-geophysical study. Tectonics 5:553-572

Perkins D III (1979) Application of New Thermodynamic Data to Mineral Equilibria. PhD Thesis Univ Michigan

Perkins D III (1983) The stability of Mg-tich garnet in the system $\mathrm{CaO}-\mathrm{MgO}-\mathrm{Al}_{2} \mathrm{O}_{3}-\mathrm{SiO}_{2}$ at $1000-1300^{\circ} \mathrm{C}$ and high pressure. Am Minerals 68:355-364

Perkins D III, Chipera SJ (1985) Garnet-orthopyroxene-plagioclase-quartz barometry: refinement and application to the English River Subprovince and the Minnesota River Valley. Contrib Mineral Petrol 89:69-80

Perkins D III, Newton, RC (1980) The composition of coexisting pyroxenes and garnet in the system $\mathrm{CaO}-\mathrm{MgO}-\mathrm{Al}_{2} \mathrm{O}_{3}-\mathrm{SiO}_{2}$ at $900^{\circ}-1100^{\circ} \mathrm{C}$ and high pressures. Contrib Mineral Petrol 75:291-300

Perkins D III, Holland TJB, Newton RC (1981) The $\mathrm{Al}_{2} \mathrm{O}_{3}$ contents of enstatite in equilibrium with garnet in the system $\mathrm{MgO}$ $-\mathrm{Al}_{2} \mathrm{O}_{3}-\mathrm{SiO}_{2}$ at $15-40 \mathrm{kbar}$ and $900^{\circ}-1600^{\circ} \mathrm{C}$. Contrib Mineral Petrol 78:99-109

Phillips GN (1978) Metamorphism and Geochemistry of the Willyama complex, Broken Hill. PhD Thesis Monash Univ

Richardson SW, Bell PM, Gilbert MC (1968) Kyanite-sillimanite equilibrium between $700^{\circ}$ and $1500^{\circ} \mathrm{C}$. Am J Sci 266:513541

Robie RA, Bin Z, Hemingway BS, Barton MD (1987) Heat capacity and thermodynamic properties of andradite garnet, $\mathrm{Ca}_{3} \mathrm{Fe}_{2} \mathrm{Si}_{3} \mathrm{O}_{12}$, between 10 and $1000 \mathrm{~K}$ and revised values of $\Delta_{f} G_{m}^{\circ}(298.15)$ of hedenbergite and wollastonite. Geochim Cosmochim Acta 51:2219-2224

Robie RA, Hemingway BS (1984) Entropies of kyanite, andalusite, and sillimanite: additional constraints on the pressure of the $\mathrm{Al}_{2} \mathrm{SiO}_{5}$ triple point. Am Mineral 69:298-306
Robie RA, Hemingway BS, Fisher JR (1979) Thermodynamic properties of minerals and related substances at $298.15 \mathrm{~K}$ and 1 bar $\left(10^{5}\right.$ pascals $)$ and at higher temperatures. US Geol Surv Bull 1452

Robinson GR Jr, Haas JL Jr, Schafer CM, Haselton HT (1982) Thermodynamic and thermophysical properties of selected phases in the $\mathrm{MgO}-\mathrm{SiO}_{2}-\mathrm{H}_{2} \mathrm{O}-\mathrm{CO}_{2}, \mathrm{CaO}-\mathrm{Al}_{2} \mathrm{O}_{3}$ $-\mathrm{SiO}_{2}-\mathrm{H}_{2} \mathrm{O}-\mathrm{CO}_{2}$, and $\mathrm{Fe}-\mathrm{FeO}-\mathrm{Fe}_{2} \mathrm{O}_{3}-\mathrm{SiO}_{2}$ systems, with special emphasis on the properties of basalts and their mineral components. US Geol Surv Open-File Rept 83-79

Robinson GR Jr, Haas JL Jr (1983) Heat capacity, relative enthalpy, and calorimetric entropy of silicate minerals: an empirical method of prediction. Am Minerals 68:541-553

Sanders IS, Daly JS, Davies GR (1987) Late Proterozoic high pressure granulite facies metamorphism in the north-east Ox Inlier, north-west Ireland. J Meta Geol 5:69-85

Sharp ZD (1988) Metamorphism and Oxygen Isotope Geochemistry of the Northern Wind River Range, Wyoming. PhD Thesis Univ Michigan

Sharp ZD, Essene EJ, Anovitz LM, Metz GW, Westrum EF Jr, Hemingway BS, Valley JW (1986) The heat capacity of a natural monticellite and phase equilibria in the system $\mathrm{CaO}-\mathrm{MgO}$ $-\mathrm{SiO}_{2}-\mathrm{CO}_{2}$. Geochim Cosmochim Acta 50:1475-1484

Skinner BJ (1966) Thermal Expansion. In: Clark SP Jr (ed) Handbook of physical constants, Geol Soc Am Mem 97:75-96

Srikantappa C, Raith M, Ackermand D (1985) High-grade regional metamorphism of ultramafic and mafic rocks from the Archaean Sargur Terrane. Karnataka, south India. Precambrian Res 30:189-219

Stoddard EF (1976) Granulite Facies Metamorphism in the ColtonRainbow Falls Area, Northwest Adirondacks, New York. PhD Thesis Univ California Los Angeles

Suwa Y, Tami Y, Naka S (1976) Stability of synthetic andradite at atmospheric pressure. Am Mineral 61:26-28

Tella S, Eade KE (1986) Occurrence and possible tectonic significance of high-pressure granulite fragments in the Tulemalu Fault Zone, District of Keewatin, N.W.T., Canada. Can J Earth Sci 23:1950-1962

Thompson DL (1983) The nature of anorthosite-country rock interaction during granulite facies metamorphism: an example from the Whitestone Anorthosite. MS Thesis McMaster University

Vaidya SN, Bailey S, Pasternack T, Kennedy GC (1973) Compressibility of fifteen minerals to 45 kilobars. J Geophys Res 78:68936898

Wagner ME, Srogi L (1987) Early Paleozoic metamorphism at two crustal levels and a tectonic model for the Pennsylvania-Delaware Piedmont. Geol Soc Am Bull 99:113-126

Wells PRA (1977) Chemical and thermal evolution of Archaean sialic crust, southern West Greenland. J Petrol 20:187-226

Winter JK, Ghose S (1979) Thermal expansion and high-temperature crystal chemistry of the $\mathrm{Al}_{2} \mathrm{SiO}_{5}$ polymorphs. Am Mineral 64:573-586

Wood BJ (1975) The influence of pressure, temperature and bulk composition on the appearance of garnet in orthogneisses an example from South Harris, Scotland. Earth Plan Sci Lett $26: 299-311$

Wood BJ, Banno S (1973) Garnet-orthopyroxene and orthopyroxene-clinopyroxene relationships in simple and complex systems. Contrib Mineral Petrol 42:109-124

Wood BJ, Holloway JR (1984) A thermodynamic model for subsolidus equilibria in the system $\mathrm{CaO}-\mathrm{MgO}-\mathrm{Al}_{2} \mathrm{O}_{3}-\mathrm{SiO}_{2}$. Geochim Cosmochim Acta 48:159-176

Editorial responsibility: J. Ferry

Received January 2, 1988/Accepted April 11, 1988 


\section{Appendix I}

Mineral formulae, abbreviations, and symbols

Albite $(A b)$ :

Almandine $(A l m)$ :

Anorthite $(A n)$ :

Andradite $(A n d)$ :

Corundum (Cor):

Diopside $(D i)$ :

Enstatite $(E n)$ :

Fayalite $(F a)$ :

Ferrosilite $(F s)$ :

Grossular $(G r)$ :

Hematite $(\mathrm{Hm})$ :

Kyanite $(K y)$ :

Mg-Tschermakite $\left(M g T_{S}\right)$ :

Magnetite $(M t)$ :

Pyrope $(P y)$ :

Quartz $(Q z)$ :

Sillimanite (Sill):

Wollastonite $(W o)$ :

$\mathrm{NaAlSi}{ }_{3} \mathrm{O}_{8}$

$\mathrm{Fe}_{3} \mathrm{Al}_{2} \mathrm{Si}_{3} \mathrm{O}_{12}$

$\mathrm{CaAl}_{2} \mathrm{Si}_{2} \mathrm{O}_{8}$

$\mathrm{Ca}_{3} \mathrm{Fe}_{2} \mathrm{Si}_{3} \mathrm{O}_{12}$

$\mathrm{Al}_{2} \mathrm{O}_{3}$

$\mathrm{CaMgSi}_{2} \mathrm{O}_{6}$

$\mathrm{MgSiO}_{3}$

$\mathrm{Fe}_{2} \mathrm{SiO}_{4}$

$\mathrm{FeSiO}_{3}$

$\mathrm{Ca}_{3} \mathrm{Al}_{2} \mathrm{Si}_{3} \mathrm{O}_{12}$

$\mathrm{Fe}_{2} \mathrm{O}_{3}$

$\mathrm{Al}_{2} \mathrm{SiO}_{5}$

$\mathrm{Mg}_{0.5} \mathrm{AlSi}_{0.5} \mathrm{O}_{3}$

$\mathrm{Fe}_{3} \mathrm{O}_{4}$

$\mathrm{Mg}_{3} \mathrm{Al}_{2} \mathrm{Si}_{3} \mathrm{O}_{12}$

$\mathrm{SiO}_{2}$

$\mathrm{Al}_{2} \mathrm{SiO}_{5}$

$\mathrm{CaSiO}_{3}$

$C c$ : calcite

Cpx: clinopyroxene

$G t$ : garnet

$\mathrm{Hbl}$ : hornblende

$K f s$ : potassium feldspar

Opx: orthopyroxene

$\mathrm{Pg}$ : plagioclase

Scap: scapolite

Ti: titanite

$\Delta G_{298}^{\circ}:$ Gibbs free energy of reaction at STP $(\mathrm{kJ} / \mathrm{mol})$

$V_{298}^{\circ}(j)$ : molar volume of phase $j$ at STP $\left(\mathrm{cm}^{3} / \mathrm{mol}\right)$

$S_{298}^{\circ}(j)$ : molar entropy of phase $j$ at STP $(\mathrm{J} / \mathrm{mol} \cdot \mathrm{K})$

$\Delta V$ : volume change of reaction

$\Delta S$ : entropy change of reaction

$X_{j}^{i}$ : mole fraction of component $i$ in phase $j$

$\gamma_{j}^{i}$ : activity coefficient of component $i$ in phase $j$

$a_{j}^{i}$ : activity of component $i$ in phase $j$

$P$ : pressure, $\mathrm{kbar}$

$T$ : temperature, $\mathrm{K}$ or ${ }^{\circ} \mathrm{C}$ where stated

$K$ : equilibrium constant

$R$ : ideal gas constant, $8.3145 \mathrm{~J} / \mathrm{mol} \cdot \mathrm{K}$

\section{Appendix II}

\section{Activity models}

Pyroxene. The ideal activity models for clinopyroxene used in this study are summarized in the text, equations 17 and 18 for hedenbergite and diopside, respectively. The model used for orthopyroxene is that of Wood and Banno (1973) in which the activity of ferrosilite is taken as:

$a_{\mathrm{Fe}_{2} \mathrm{Si}_{2} \mathrm{O}_{6}}^{\mathrm{Opx}}=\left[X_{\mathrm{Fe}^{2+}}^{\mathrm{M} 1}\right]\left[X_{\mathrm{Fe}^{2+}}^{\mathrm{M} 2}\right]$.

Pyroxene analyses are normalized to 4 cations and $\mathrm{Fe}^{3+}$ is calculated from charge balance and stoichiometry. After subtracting the atomic amounts of $\mathrm{Ca}, \mathrm{Na}$, and $\mathrm{Mn}$ from the $\mathrm{M} 2$ site, and subtracting $\mathrm{Al}^{\mathrm{vi}}, \mathrm{Ti}, \mathrm{Cr}$, and $\mathrm{Fe}^{3+}$ from the $\mathrm{Ml}$ site, $\mathrm{Fe}^{2+}$ is partitioned into each remaining site in the same ratio as $\mathrm{Fe}^{2+} /\left(\mathrm{Fe}^{2+}+\mathrm{Mg}\right)$ in the mineral.

The equilibrium constant for the FS barometer includes a term for $a_{\mathrm{Fe}_{2} \mathrm{Si}_{2} \mathrm{O}_{6}}^{\mathrm{Opx}}$ that is raised to the 3 rd power. Because the two site model squares $X_{\mathrm{Fs}}$, the activity of ferrosilite calculated above is taken to the 3 rd power in calculating the equilibrium constant for Reaction 3, although the thermodynamic data for ferrosilite are based on a 2 cation formula (6 moles of Fs for Reaction 3 ). When calculating the activity of $\mathrm{FeSiO}_{3}$ simply as mole fraction of $\mathrm{Fe}^{2+}$, the exponent for Fs in Reaction 3 is raised to the 6th power.

Plagioclase. Anorthite activities were calculated according to the model of Newton et al. (1980), also given in Newton and Haselton (1981), Newton and Perkins (1982), and Newton (1983). Plagioclase analyses were normalized to 5 cations, and $X_{\mathrm{An}}^{\mathrm{Pg}}=\mathrm{Ca} /(\mathrm{Ca}+\mathrm{Na})$. The activity of anorthite is calculated from the following relations:

$R T I n \gamma_{\mathrm{An}}^{\mathrm{Pg}}=\left(X_{\mathrm{Ab}}^{\mathrm{Pg}}\right)^{2}\left[2050+9392 X_{\mathrm{An}}^{\mathrm{Pg}}\right]$
$a_{\mathrm{CaAl}_{2} \mathrm{Si}_{2} \mathrm{O}_{8}}^{\mathrm{Pg}}=\gamma_{\mathrm{An}}^{\mathrm{Pg}}\left[X_{\mathrm{Mg}}^{\mathrm{Gt}}-\left(1+X_{\mathrm{An}}^{\mathrm{Pg}}\right)^{2}\right] / 4$

Garnet. Grossular, pyrope, and almandine activities were calculated using the quaternary garnet mixing model of Ganguly and Saxena (1984), with the $\mathrm{Ca}-\mathrm{Fe}$ mixing parameters for the grossular-almandine join calculated by Anovitz and Essene (1987a). The Ca-Mg, $\mathrm{Ca}-\mathrm{Mn}, \mathrm{Fe}-\mathrm{Mg}, \mathrm{Fe}-\mathrm{Mn}$, and $\mathrm{Mg}-\mathrm{Mn}$ mixing parameters are the same as in Ganguly and Saxena (1984). Use of these parameters yields the following analytical expressions for the activity coefficient of grossular, pyrope, and almandine:

$$
\begin{aligned}
& R T \operatorname{In} \gamma_{\mathrm{Ca}}^{\mathrm{Gt}}=\left(X_{\mathrm{Mg}}^{\mathrm{Gt}}\right)^{2}\left(4047-1.5 T-6094 X_{\mathrm{Ca}}^{\mathrm{Gt}}\right) \\
& +\left(X_{\mathrm{Fe}^{2+}}^{\mathrm{Gt}}\right)^{2}\left(150-1.5 T+7866 X_{\mathrm{Ca}_{a}}^{\mathrm{Gt}}\right) \\
& +X_{\mathrm{Mg}}^{\mathrm{Gt}} X_{\mathrm{Fe}^{2}+}^{\mathrm{Gt}}\left[3290-3.0 T+886 X_{\mathrm{Ca}}^{\mathrm{Gt}}+2300\left(X_{\mathrm{Mg}}^{\mathrm{Gt}}\right.\right. \\
& \left.-X_{\mathrm{Fe}^{2+}}^{\mathrm{Gt}}\right) \\
& \left.+4640\left(1-2 X_{\mathrm{Ca}}^{\mathrm{Gt}}\right)\right] \\
& +X_{\mathrm{Fe}^{2}+}^{\mathrm{Gt}} X_{\mathrm{Mn}}^{\mathrm{Gt}}\left[2117-1.5 T+3933 X_{\mathrm{Ca}}^{\mathrm{Gt}}-1967\left(1-2 X_{\mathrm{Ca}}^{\mathrm{Gt}}\right)\right] \\
& +X_{\mathrm{Mg}}^{\mathrm{Gt}} X_{\mathrm{Mn}}^{\mathrm{Gt}}\left[2524-1.5 T-3047 X_{\mathrm{Ca}}^{\mathrm{Gt}}+1524\left(1-2 X_{\mathrm{Ca}}^{\mathrm{Gt}}\right)\right] \\
& +2300\left[X_{\mathrm{Mg}}^{\mathrm{Gt}} X_{\mathrm{Fe}^{2}}^{\mathrm{Gt}} X_{\mathrm{Mn}}^{\mathrm{Gt}}\right] \\
& R T \operatorname{In} \gamma_{\mathrm{Mg}}^{\mathrm{Gt}}=\left(X_{\mathrm{Ca}}^{\mathrm{Gt}}\right)^{2}\left(1000-1.5 T+6094 X_{\mathrm{Mg}}^{\mathrm{Gt}}\right) \\
& +\left(X_{\mathrm{Fe}^{2+}}^{\mathrm{Gt}}\right)^{2}\left(2500-4600 X_{\mathrm{Mg}}^{\mathrm{Gt}}\right)+3000\left(X_{\mathrm{Mn}}^{\mathrm{Gt}}\right)^{2} \\
& +X_{\mathrm{Ca}}^{\mathrm{Gt}} X_{\mathrm{Fe}^{2}}^{\mathrm{Gt}}\left[1757+747 X_{\mathrm{Mg}}^{\mathrm{Gt}}-3933\left(X_{\mathrm{Ca}}^{\mathrm{Gt}}-X_{\mathrm{Fe}^{2+}}^{\mathrm{Gt}}\right)\right. \\
& \left.+4640\left(1-2 X_{\mathrm{Mg}}^{\mathrm{Gt}}\right)\right] \\
& +X_{\mathrm{Fe}^{2}}^{\mathrm{Gt}} X_{\mathrm{Mn}}^{\mathrm{Gt}}\left[4350-2300 X_{\mathrm{Mg}}^{\mathrm{Gt}}+1150\left(1-2 X_{\mathrm{Mg}}^{\mathrm{Gt}}\right)\right] \\
& +X_{\mathrm{Ca}}^{\mathrm{Gt}} X_{\mathrm{Mn}}^{\mathrm{Gt}}\left[5524+3047 X_{\mathrm{Mg}}^{\mathrm{Gt}}-1524\left(1-2 X_{\mathrm{Mg}}^{\mathrm{Gt}}\right)\right] \\
& +3933\left[X_{\mathrm{Ca}}^{\mathrm{Gt}} X_{\mathrm{Fe}^{2}}^{\mathrm{Gt}} X_{\mathrm{Mn}}^{\mathrm{Gt}}\right] \\
& \left.R T \operatorname{In} \gamma_{\mathrm{Fe}^{2+}}^{\mathrm{Gt}}=\left(X_{\mathrm{Mg}}^{\mathrm{Gt}}\right)^{2} 200+4600 X_{\mathrm{Fe}^{2+}}^{\mathrm{Gt}}\right) \\
& +\left(X_{\mathrm{Ca}}^{\mathrm{Gt}}\right)^{2}\left(4083-1.5 T-7866 X_{\mathrm{Fe}^{2+}}^{\mathrm{Gt}}\right) \\
& +X_{\mathrm{Mg}}^{\mathrm{Gl}} X_{\mathrm{Ca}}^{\mathrm{Gt}}\left[943-1633 X_{\mathrm{Fe}^{2+}}^{\mathrm{Gt}}-3047\left(X_{\mathrm{Mg}}^{\mathrm{Gt}}-X_{\mathrm{Ca}}^{\mathrm{Gt}}\right)\right. \\
& \left.-4640\left(1-2 X_{\mathrm{Fe}^{2+}}^{\mathrm{Gi}}\right)\right] \\
& +X_{\mathrm{Ca}}^{\mathrm{Gt}} X_{\mathrm{Mn}}^{\mathrm{Gt}}\left[2117-1.5 T-3933 X_{\mathrm{Fe}^{2+}}^{\mathrm{Gt}}+1917(1\right. \\
& \left.-2 X_{\mathrm{Fe}^{2+}}^{\mathrm{Gt}}\right] \\
& +X_{\mathrm{Mg}}^{\mathrm{Gt}} X_{\mathrm{Mn}}^{\mathrm{Gt}}\left[-1650+2300 X_{\mathrm{Fe}^{2+}}^{\mathrm{Gt}}-1150\left(1-2 X_{\mathrm{Fe}^{2+}}^{\mathrm{Gt}}\right)\right] \\
& +3048\left[X_{\mathrm{Mg}}^{\mathrm{Gt}} X_{\mathrm{Ca}}^{\mathrm{Gt}} X_{\mathrm{Mn}}^{\mathrm{Gt}}\right] \text {. }
\end{aligned}
$$

Because there are three equivalent 8-coordinated sites in garnet, the activity of $\mathrm{Ca}_{3} \mathrm{Al}_{2} \mathrm{Si}_{3} \mathrm{O}_{12}, \mathrm{Mg}_{3} \mathrm{Al}_{2} \mathrm{Si}_{3} \mathrm{O}_{12}$, and $\mathrm{Fe}_{3} \mathrm{Al}_{2} \mathrm{Si}_{3} \mathrm{O}_{12}$ are calculated as

$a_{\mathrm{Ca}_{3} \mathrm{Al}_{2} \mathrm{Si}_{3} \mathrm{O}_{12}}^{\mathrm{Gt}}=\left(X_{\mathrm{Ca}}^{\mathrm{Gt}} \gamma_{\mathrm{Ca}}^{\mathrm{Gt}}\right)^{3}$,

$a_{\mathrm{Mg}_{3} \mathrm{Al}_{2} \mathrm{Si}_{3} \mathrm{O}_{12}}^{\mathrm{Gt}}=\left(X_{\mathrm{Mg}}^{\mathrm{Gt}} \gamma_{\mathrm{Mg}}^{\mathrm{Gt}}\right)^{3}$, and

$a_{\mathrm{Fe}_{3} \mathrm{Al}_{2} \mathrm{Si}_{3} \mathrm{O}_{12}}^{\mathrm{Gt}}=\left(X_{\mathrm{Fe}^{2+}}^{\mathrm{Gt}} \gamma_{\mathrm{Fe}^{2+}}^{\mathrm{Gt}}\right)^{3}$.

Garnet analyses are normalized to 8 cations with $\mathrm{Fe}^{3+}$ calculated form charge balance and stoichiometry. For garnets with $\mathrm{Si}>3.00$, $\mathrm{Fe}^{3+}$ was calculated from the relation $\mathrm{Fe}^{3+}=2-\mathrm{Al}-2 \mathrm{Ti}-\mathrm{Cr}$. 